\title{
Switching from import substitution to the 'New Economic Model' in Latin America : A case of not learning from Asia
}

Citation for published version (APA):

Narula, R. (2002). Switching from import substitution to the 'New Economic Model' in Latin America : A case of not learning from Asia. MERIT, Maastricht Economic Research Institute on Innovation and Technology. MERIT-Infonomics Research Memorandum Series No. 032 https://doi.org/10.26481/umamer.2002032

Document status and date:

Published: 01/01/2002

DOI:

10.26481/umamer.2002032

Document Version:

Publisher's PDF, also known as Version of record

Please check the document version of this publication:

- A submitted manuscript is the version of the article upon submission and before peer-review. There can be important differences between the submitted version and the official published version of record.

People interested in the research are advised to contact the author for the final version of the publication, or visit the DOI to the publisher's website.

- The final author version and the galley proof are versions of the publication after peer review.

- The final published version features the final layout of the paper including the volume, issue and page numbers.

Link to publication

\footnotetext{
General rights rights.

- You may freely distribute the URL identifying the publication in the public portal. please follow below link for the End User Agreement:

www.umlib.nl/taverne-license

Take down policy

If you believe that this document breaches copyright please contact us at:

repository@maastrichtuniversity.nl

providing details and we will investigate your claim.
}

Copyright and moral rights for the publications made accessible in the public portal are retained by the authors and/or other copyright owners and it is a condition of accessing publications that users recognise and abide by the legal requirements associated with these

- Users may download and print one copy of any publication from the public portal for the purpose of private study or research.

- You may not further distribute the material or use it for any profit-making activity or commercial gain

If the publication is distributed under the terms of Article 25fa of the Dutch Copyright Act, indicated by the "Taverne" license above, 


\section{MERIT-Infonomics Research Memorandum series}

Switching from import substitution to the 'New Economic Model' in Latin America: A case of not learning from Asia

\section{Rajneesh Narula}

2002-032

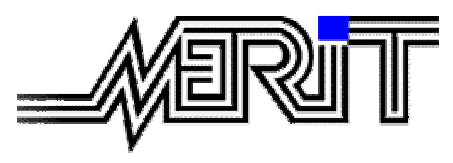

MERIT - Maastricht Economic Research Institute on Innovation and Technology

PO Box 616

6200 MD Maastricht

The Netherlands

T: +31433883875

F: +31433884905

http://meritbbs.unimaas.nl

e-mail:secr-merit@merit.unimaas.nl

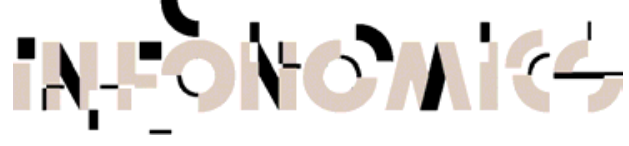

International Institute of Infonomics

c/o Maastricht University

PO Box 616

6200 MD Maastricht

The Netherlands

$\mathrm{T}:+31433883875$

F: +31453884905

http://www.infonomics.nl

e-mail: secr@infonomics.nl 


\title{
Switching from import substitution to the 'New Economic Model' in Latin America: A case of not learning from Asia ${ }^{1}$
}

\author{
Rajneesh Narula \\ Copenhagen Business School \& University of Oslo
}

\begin{abstract}
This paper argues that the East Asian success stories do not owe their growth to liberalised markets and laissez faire industrial policies, but to industrial development strategies that share several similarities to the import-substitution industrialisation (ISI) approach. There are, needless to say, some important fundamental differences which determine why Latin America and East Asia demonstrated such different outcomes, but these have become obvious only with hindsight. Nonetheless, the switch from ISI to the Washington Consensus-derived, neo-liberal 'New Economic Model' (NEM) has not in any way minimised these differences. I argue that the NEM - as currently formulated - cannot sustain long-term industrial development, and is likely to erode the gains made from ISI programmes for the sake of efficiency and export growth. The ISI-to-NEM shift has not reoriented Latin America towards the East Asian model but away from it. I identify five important problems with the ISI restructuring model which have reduced the opportunities for duplicating the east Asian success story, 1.The attenuation of the role of government; 2 . unreasonable expectations from the liberalisation of FDI for industrial development; 3 . the failure to sustain absorptive capacity; 4 . The failure to sequence FDI and domestic capacity in tandem; and 5. The failure to recognise the inertia of transition, and coordination failures.
\end{abstract}

\section{Biographical note}

Rajneesh Narula is Professor at the Copenhagen Business School, and the Centre for Technology, Innovation and Culture (TIK Centre), University of Oslo. His interests include foreign direct investment, R\&D alliances and technology policy.

\footnotetext{
${ }^{1}$ This paper was commissioned by the Inter-American Development Bank. The first draft was presented at the LAEBA panel held in Paris at the Strategic Management Society Annual International Conference in Paris, September 22-25, 2002. Conversations with Sanjaya Lall, Lou Anne Barclay and Rajah Rasiah have proved critical in developing this paper, and I gratefully acknowledge their input. All errors are my own.
} 


\title{
Switching from import substitution to the 'New Economic Model' in Latin America: A case of not learning from Asia
}

\author{
Rajneesh Narula \\ Copenhagen Business School \& University of Oslo
}

\section{$\underline{1 . \text { Introduction }}$}

At the risk of oversimplification, there has been a volte face in terms of policy perspectives among developing countries. During much of the post WWII era, the development strategies in these countries revolved around the concept of catching-up through the fostering of domestic industrial capacity. The origins of this approach are not new: Since at least the late $18^{\text {th }}$ century when most western countries sought to 'catch-up' with Britain, the centrepiece of industrial development used much the same approach, with the basic principles laid out by Smith (1776), Hamilton (1791) and List (1844) among others. Every nation state considered it essential to possess national capacity in so-called 'essential' industries. Inward FDI and trade were largely controlled and limited in their scope, unless it met stringent conditions that promoted the self-sufficiency view by enhancing the host country's domestic sector. This view considered government intervention as a necessary tool for promoting infant industries. Although the developing countries have used several variations of this approach, this paper will focus on contrasting two particular industrial development strategies, the first was the 'pure' import-substitution industrialisation (ISI) model favoured by Latin America, and the export-oriented (but still very much interventionist) model favoured by Japan, and the Asian NICs.

Over the last 15 years or so - whether voluntarily or through World Bank-sanctioned structural adjustment programs -the focus of the first group has shifted away from promoting domestic industrial development towards policies promoting economic efficiency and the role of the market. Policies are oriented towards export-led growth and increased cross-border specialisation and competition, and most countries are now trying to promote economic growth through FDI and international trade - what has been referred to as the 'New Economic Model' (NEM) (Reinhardt and Peres 2000). The NEM draws some of its inspiration from the belief that the success of the second group - the Asian NICs - derives from just such an 
approach $^{2}$. This wave of liberalisation is part of the new, received wisdom that is focused on tackling the deep-rooted causes that underlie market distortions, because the new orthodoxy regards markets as being generally efficient. Indeed, tariff rates in Latin America have fallen from an average of $24.1 \%$ during 1986-90, to $11.1 \%$ during 1996-1999. The equivalent figures for East Asia are 20.7\% and 10.4\% (Hoekman 2002). Non-tariff barriers have also come down substantially, and are on average half those in East Asia (Hoekman 2002). Subsidies and state interventions have been drastically reduced, with markets and efficiency being paramount. Restrictions on FDI have been eased, and in many cases completely eliminated. Despite the application of this new orthodoxy, results from Latin America (where the NEM has most systematically been applied) indicate that these new policies have produced mixed results at best.

It is important to emphasise two points. First that different countries applied the ISI framework to differing extents. There is a wide range of experiences with ISI, because the ISI approach requires implementation of a wide variety of policies and interventions at multiple levels, from establishing and enforcing industrial, technological and sectoral targeting, the promotion of local content, the acquisition and upgrading of technologies, the creation of basic and knowledge infrastructure, and infrastructure. In addition, policies and institutions on competition, procurement, tariffs, subsidies, regulation and the like need to be established and applied concurrently to achieve industrial development. This is exceedingly complicated and is done within the framework of social, political and cultural institutions, which affect and shape the effectiveness of any strategy. Different social and political groups, furthermore, have vested interests and obligations which must be maintained and affect the rigour with which particular policies are applied in practice. Thus Latin America consists of a wide variety of outcomes, with countries such as Brazil and Chile having more successfully harnessed opportunities, relative to Argentina or Colombia. In Asia, likewise, India's ISI programmes built up considerable capacity, relative to the Philippines.

For similar reasons, the implementation of the NEM has occurred equally unevenly. India and Brazil have sought a middle ground between NEM-type liberalisation and ISI, while Mexico has adopted the NEM, lock, stock and barrel. Thus, both ISI and NEM are stylised terminologies as used here, as is the concept of a single 'Latin American experience' or an 'Asian' or 'East Asian experience'. I realise I am in danger of over-generalising, but I believe important lessons can be drawn from a broad brush-stroke study such as this.

\footnotetext{
${ }^{2}$ See World Bank (1994).
} 
Second, Mexico's post ISI experience cannot be viewed in the same light as that of the rest of Latin America. Reinhardt and Peres (2000) argue that a clear distinction can be made between countries north and south of Panama: Countries north of Panama have the advantage of geographical proximity to the US, and US policies have actively promoted trade and investment with these countries. This is most obvious in Mexico, which has been fully integrated within NAFTA. The Caribbean countries are also more closely linked to the US through a series of multilateral and bilateral arrangements. Proximity with, and special trading relationships to the US act as a unique locational advantage, which are not discussed here.

This paper takes as a starting point - shared by a large number of scholars ${ }^{3}$ - that the East Asian success stories do not in fact owe their growth to liberalised markets and laissez faire industrial policies, but to domestic industrial development strategies that share several similarities to the ISI approach. There are, needless to say, some important fundamental differences which determine why these two groups of countries demonstrated such different outcomes, but these have become obvious only with hindsight. Nonetheless, the switch from ISI to NEM has not in any way minimised these differences, and, if anything, the hybrid 'ISI restructuring model' (which is a result of superimposing NEM policies on systems weaned on ISI policies) is even further away ideologically from the East Asian experience. This paper takes the view that the NEM - as currently formulated - cannot sustain long-term industrial development, and is likely to erode the gains made from ISI programmes for the sake of efficiency and export growth.

\section{Classifying development stages and policies: some taxonomies}

Comparing any two countries is a task fraught with complications. Comparing two regions with individual countries as diverse and heterogeneous in and amongst themselves is even more complex.

\section{***TABLE 1 ABOUT HERE***}

It is probably most useful to distinguish between the countries in the two regions along two dimensions. First, as table 1 illustrates, there is considerable variation in the level of economic development, basic demography and income levels. It is axiomatic that these issues determine the kinds of economic activity, domestic industrial structure and foreign direct investment associated with them, which reflects the economic structure and the nature of the country's technological capabilities. We can distinguish between four stages of knowledge

\footnotetext{
${ }^{3}$ See e.g., (Wade 1988, 1990), Nelson and Pack (1995), Pack (2001), Lall (1990, 1996, 2002), Amsden (1989, 2001), Rodrik (1999)
} 
accumulation: the pre-catching up stage, the catching-up stage, the pre-frontier-sharing stage, and the frontier-sharing stage (Criscuolo and Narula 2002). Some general characteristics of these stages are highlighted in table 2 . Generally speaking, pre-catching-up countries are the least developed countries with low GDP per capita and poorly developed technological capabilities, and include countries such as Bolivia, Vietnam and Paraguay. These countries have yet to develop an "adequate" minimum level of technological capacity. Acquiring and sustaining this threshold level of absorptive capacity occurs in the 'pre-catching-up' stage. Catching-up countries have achieved the necessary threshold level of technological capacity (as indicated by the presence of basic infrastructure, some level of knowledge infrastructure and a certain domestic industrial capacity), such as China, India, Malaysia, Brazil, Chile, Argentina. As any given country approaches the technological frontier ${ }^{4}$, the accumulation process proceeds at a slower pace ('the pre-frontier-sharing' stage). The assimilation of external knowledge becomes more difficult, both because of the increasing complexity and the quantity of knowledge, and the difficulties of acquiring this knowledge. Pre-frontiersharing countries are in the process of converging on the frontier, and are mainly the so-called Asian NICs, and include Taiwan and Korea.

\section{***TABLE 2 ABOUT HERE***}

It is necessary too, to distinguish between policy orientations, with regards to developing and upgrading domestic competitiveness. Although there is a tendency to regard economies within a dichotomy of either an outward-oriented, export-oriented policy orientation (OL-EO), or an inward-looking, import/substituting orientation (IL-IS) (Ozawa 1992, Narula 1996). This is naturally an oversimplification of reality, since in reality there tends to be a hybrid policy orientation. For the purposes of this paper, I want to distinguish between the various Asian experiences from the Latin American experiences. We utilise a taxonomy based on Lall (2002), who distinguishes between for different approaches, which are not exclusive. The East Asian experience can be classified into three different types:

East Asian model (1): Autonomous strategy. This is the model undertaken by Korea, and to a lesser extent, Taiwan. The primary objective was the upgrading of domestic firms, by selective restrictions on FDI (in the case of Taiwan), and the use of technology imports (in the case of Korea). In other words, foreign participation was largely limited in targeted sectors, with complex industrial policies that encouraged upgrading. The yard stick for industrial development - and indeed, the objective - was to promote competitiveness in exporting, and

\footnotetext{
${ }^{4}$ We define the technological frontier as the set of all production methods that at any given time are either most economical or most productive in the world.
} 
this determined which sectors were targeted, and the extent to which subsidies and incentives were provided.

East Asian model (2): Strategic FDI dependent strategy. This strategy is best exampled by Singapore, which due to the restrictions due to its limited size, could not pursue an efficient domestic industrial base. It sought instead to attract MNE activity, and then made strong efforts to upgrade the quality of FDI towards higher value-adding activities.

East Asian model (3): Passive FDI dependent strategy In this model, FDI was also the primary driver, but instead to intervening to encourage upgrading (as with strategic FDI dependency), it relied on market forces to encourage the upgrading process. Although policies to encourage the development of 'generic' location advantages were implemented (such as infrastructure development, incentives for exports, skilled cheap labour), the development of complementary domestic industrial capacity was not developed in tandem with FDI upgrading. This model has been followed by Malaysia, Philippines, Thailand and Indonesia.

Latin America - like Asia and much of Africa - followed the ISI model. The ISI approach also had as a primary objective the upgrading of domestic firms, by selective restrictions on FDI and the use of technology imports, but focused on import-substitution, rather than promoting exports.

Since the mid 1980s, these countries are regarded to have adopted the 'ISI restructuring model'. This is a hybrid model based on a rapid transition from ISI to NEM, having undertaken trade liberalisation and export incentives, often as part of a structural adjustment programme. Some countries have relied on MNEs to drive their growth strategy, while others have depended almost entirely on domestic firms, and the inflow of technology through arms-length arrangements such as licensing.

As I have emphasised earlier, these are by no means exclusive. Several countries have used different models for different sectors, as well as switching between different models over time. There is considerable overlap between these models.

My interest in the current paper is to highlight the similarities and differences between the ISI model and the autonomous model. The next section discusses this, by taking a retrospective view, and then discusses the nature of the ISI-NEM hybrid ('ISI restructuring') 
3. Asia and Latin America: Are their approaches to industrialisation very different? Comparing ISI with the autonomous strategy

Latin American economies are individually very different, with different languages, geographies, histories and resource endowments. Nonetheless, they share a few common features. First, they have all pursued an import-substituting, inward looking policy orientation for the several decades prior to the current trend towards liberalisation, roughly until to the early 1990s. Indeed, the ideas and principles behind the Dependencia School are native to Latin America. Second - but not entirely unrelated to the first point - there has been a long love-hate relationship between the US and Latin America stretching back to the late $19^{\text {th }}$ century. The US has regarded the South American continent as its backyard, and has been the largest trading and investment partner for over a century now. In addition, it has intervened politically and militarily on numerous occasions to maintain its economic and political dominance of the region. Third, most countries in the Latin America have been politically independent for over a 100 years, insofar as they are self-governing. Fourth, they have had a historical dependence on natural resource and extractive industries, a trend which the importsubstitution policies implemented in the 1950s and 1960s were to have helped reduce. These issues have- intentionally or not - coloured the attitudes of government policies towards industrial development, as well as the kinds of FDI that have been received by Latin American countries within the current wave of economic liberalisation.

At the risk of oversimplifying a complex set of developments ${ }^{5}$, the doctrine of import substitution took hold in the post World War II era, whereby leading economists of the day rejected the market solution as a means for the under-developed south to catch-up with the developed north, by moving away from exporting primary commodities and importing manufactures, towards developing a domestic industrial base. This, it was argued, would capture the rents that derived to the developed economies from value adding to the primary commodities imported from the south, and the resulting structural change would spur economic development, as well as promoting economic independence. The implementation of impost-substitution generally involved a high degree of central planning, combined with protection. Protection was undertaken through tariffs, exchange rate manipulation, quotas and exchange controls. Although one of the main objectives was to decrease manufactured

\footnotetext{
${ }^{5}$ See Bruton (1998) for an excellent overview, and which forms the basis of the discussion on import substitution here.
} 
imports, the net effect was also to discourage exports, in both manufacturing and agriculture, inter alia, because of overvalued exchange rates.

Domestic industry was to be developed by seeking capital and technology from abroad, since it was largely accepted at the time that physical capital and know-how could be transferred relatively easily through the flow of aid, turn-key projects and the provision of technical experts from the north to the south. Indeed, this view was widely held with agencies such as the World Bank promoting these technology transfer programmes (Bruton 1998).

The role of MNEs was seen as a means to actualise the process of technology transfer. Investments in most countries were permitted in targeted sectors with the explicit understanding that control, ownership and technology would gradually transfer to the domestic sector. In addition, intermediate inputs were to be phased out as domestic suppliers acquired the competence to meet the (graduated and increasing) local content stipulations that were generally included in the investment agreements. FDI was largely undertaken with the intention of supplying the local market, since neighbouring countries had implemented their own import substitution programmes. Captive markets meant that MNEs were able to pass on the costs of producing at an inefficient scale. A considerable share of productive assets were in state ownership, either as a part of the belief in central planning, or to support large capital intensive and scale-intensive projects which the private sector could not afford to maintain.

Import-substitution policies did lead to economic growth in most developing countries during the 1950s and 1960s, and even in the 1970s, although the anticipated growth of domestic manufacturing sector did not go quite as planned. This in part reflected the application of a similar ISI program in most countries, despite the considerable differences in the initial economic structure and industrial development between the various Latin American countries. ISI schemes were not adjusted to reflect differences in comparative advantages, but sought to duplicate the same breadth of industrial sectors regardless of their initial specialisation and resource endowment. It would seem axiomatic with hindsight that the import-substituting experience of countries at different stages of economic development would necessarily be different, but this was not acknowledged at the time. Countries as varied as Argentina and Peru, for instance, attempted to build up domestic expertise in automobiles and chemicals, despite it being the case that less developed countries have - in addition to a lower income level - have lower technological capabilities and an economic structure that favours resource-intensive and primary sector activities (table 2). The focus on import substituting meant that little effort was made to export manufacturing output. Even as late as 1985, manufacturing exports from Latin America were just $25.1 \%$ of all exports, less than half 
the level in east Asia where manufactures were about $51.7 \%$ of exports in the same year. Table 3 gives details of the individual countries in the two regions. It is worth noting that manufacturing value added as a percentage of GDP was roughly equal in the two regions in 1985 (Table 3). These figures suggest that domestic acquisition and transfer of technology and managerial know-how to the domestic sector was less successful in bringing Latin America up to world levels than in east Asia, and productivity of the domestic sector persistently lagged that of the Asian countries. Furthermore, although import reduction was one of the primary goals of the IS programmes, imports continued to be significant, as intermediate and capital goods still had to be imported (Bruton 1998). As late as the 1985, manufacturing imports were $61.7 \%$ of total imports in Latin America, almost identical as the same figure for East Asia and the Pacific (61\%). The one exception was Brazil where manufacturing imports accounted for just 37.9\% of imports (Table 3). Despite increasing awareness of the problems of import substitution and its effective implementation, however, many countries continued to pursue these policies, in many instances increasing the role of state ownership as a means to increase efficiency and to promote social welfare.

\section{****TABLE 3 ABOUT HERE***}

The majority of East Asian economies also implemented similar infant industry programs in the 1950s, discouraging foreign ownership wherever possible, and encouraging the development of domestic enterprise in much the same way as had Latin American and South Asian countries. While maintaining the basic objective of building up domestic manufacturing capacity, Taiwan modified its import substituting regime in the late 1950s, and Korea followed suit in the mid-1960s, seeking to encourage exports alongside the primary goal of building domestic industrial capacity. These included establishing a realistic exchange rate, and creating incentives to export (including subsidies, credit allocation, trade restrictions, and reduced or duty free access for imported inputs). Singapore went much further, dropping IS policies almost completely around the same time. The 'New NICs': Malaysia, Thailand, began to move toward a greater export orientation and friendliness towards FDI from the late 1970s onwards, although still maintaining a strong orientation towards building domestic capacity. They were later followed by Indonesia, Philippines, China, India and eventually most of Asia. The point here is that all these countries (and later Philippines) pursued industrial policies that maintained significant elements of import-substituting regimes until (and in some cases, beyond) the 1990s, very much as Latin America has done.

Thus, it is possible to say that the East Asian countries adopted a more outwardlooking, export-oriented policy orientation at a much earlier period in time than Latin 
America. I emphasise the 'more' in the last sentence because, as I have highlighted in the previous section there is considerable variation. With the possible exception of pre-1997 Hong Kong, almost all economies in the region have actively sought to intervene to support the growth and competitiveness of their domestic sector, alongside their export-orientation ${ }^{6}$. This was done through a variety of means, both by promoting domestic sectors as well as restricting imports. At $23.5 \%$, tariff rates were only marginally lower in East Asia than Latin America (28.1\%) during 1978-80, and by the period 1981-1985, were almost identical. Nontariff barriers were in fact almost twice as high in East Asia than in Latin America as late as 1989-1994 (Hoekman 2002). East Asia can therefore be said to be both export oriented and import-substituting (EO-IS) at the same time.

Latin America, however, adopted the so-called New Economic Model (NEM) only reluctantly. Unlike the East Asian 'miracle' economies, Latin America did not voluntarily seek to move towards promoting an outward orientation in tandem with its import-substituting regime, but was pressured into structural adjustment programmes due to problems with macroeconomic stability and the ensuing economic crises that engulfed them in the 1980s. To be sure, the large state-owned sector many countries was highly inefficient and in dire need of reform. However, considerable industrial development had occurred in some of these countries, particularly Chile, Argentina and Brazil, and in Asia, Indonesia and India. This made the reformation and opening up of the economy an exercise undertaken with some reluctance. Nonetheless, the NEM, which emphasises the free play of market forces both domestically and economically, was introduced as part of sweeping policy reforms beginning in the mid-1980s. The NEM is part of the new, received wisdom that is focused on tackling the deep-rooted causes that underlie market distortions, explicitly reducing state intervention such that it is applied exceptionally. The emphasis thus moved away from developing domestic capability to enhancing economic efficiency and discipline that market forces were supposed to provide (Reinhardt and Peres 2000). They therefore moved much further away from import-substitution and domestic capability enhancement, and much more rapidly so than did most East Asian economies. The NEM entailed large-scale privatisation of public sector activities, rapid dismantling of import and FDI restrictions, and the termination or attenuation of state incentives and public goods aimed at enhancing the competitiveness of domestic firms. Thus, the ISI programmes shared much in common with the autonomous strategy of Korea and Taiwan, except that in the Asian economies strong state intervention

\footnotetext{
${ }^{6}$ For a succinct discussion of these policies see Amsden (2001), as well as Lall (1996).
} 
was clearly targeted and coordinated to enhance domestic technological capabilities and competitiveness, while at the same time emphasising international markets as a benchmark. On the other hand, the NEM and the so-called ISI restructuring strategy went to the other extreme: they emphasised international markets and export competitiveness, but withdrew the support structure that allowed firms to internalise the spillovers that derived from international competition.

One of the goals of the ISI was to reduce the dependence on natural resources, as well as to increase economic independence. This particular objective was never achieved, with primary exports accounting for up to $99.6 \%$ of the exports of countries such as Bolivia (table 3 ) in 1985. The NEM has also not been able to reduce the primary sector dependency of LAC, with only marginal changes in the share of the primary sector in value added between 1985 and 1998 (Table 3). Exports of primary products has declined somewhat in favour of manufactured exports, but this probably reflects increased intra-Latin American flows in response to the regional integration schemes such as MERCOSUR. This partly explains why, despite the increase in the share of primary exports, there has been also general decline in the share of value added attributable to manufacturing in almost all Latin American economies. Most primary commodities are associated with highly volatile and cyclical markets, as has been the case with coffee and copper (among others) in the last decades, and this makes countries extremely vulnerable to external shocks due to this volatility.

Although it is difficult to speak with certainty in this matter, much of the evidence suggests that the ISI-to-NEM shift has resulted in a shock of transition, and has not reoriented Latin America towards the 'autonomous model' or the 'strategic-FDI dependent model' of East Asia, but away from it. As ECLAC (2001) emphasises, export growth has not necessarily resulted to export-led growth. We identify five important problems with the ISI restructuring model (as currently enshrined in the NEM doctrine) which have reduced the opportunities for duplicating the East Asian success story:

1. The attenuation of the role of government;

2. Unreasonable expectations from the liberalisation of FDI for industrial development;

3. The failure to sustain absorptive capacity;

4. The failure to sequence FDI and domestic capacity in tandem;

5. The failure to recognise the inertia f transition, and coordination failures.

The next 5 sections deal with these issues. 


\subsection{The attenuation of the role of government}

At the risk of over-generalising, the NEM has reduced the role of the state in Latin America to an extent that the crucial point of the autonomous strategy - the role of governments in promoting the proactive process of industrial upgrading -has largely been ignored. Indeed, the role of the state has been significant in the industrial development strategies of the East Asian economies (see e.g., Amsden 1989, Hobday 1995, Wade 1990, Lall 1996, Pack 2001).

Nonetheless, given the debt crises and liquidity problems of Latin America, it needs to be acknowledged that the opportunity costs of national governments in pursuing a strategy of promoting technological development are quite high, both in terms of creating the necessary infrastructure- including clusters of related activities- and of sustaining the requisite macroorganizational policies and financial incentives over an extended period of time. In the main, the smaller and/or poorer developing countries cannot afford to invest in several niches simultaneously, and as such the question of technological targeting (i.e., picking the 'right' sectors) becomes critical.

State involvement among the Latin American countries has declined considerably with the introduction of the NEM. Perhaps the greatest change has been the reduction in state ownership and the subsequent privatisation of assets. Between 1988 and 1999, \$107.3 billion worth of privatised firms had been acquired through cross-border M\&A. The share of Latin America and the Caribbean was roughly $79.8 \%$ (UNCTAD 2000). In other words, during this period, about $20 \%$ of the total inflows to this region were associated with privatisation. During the period 1999-2000 alone, privatisations totalled US\$ 19.5 billion, of which US\$4.7 billion was directed at primary sector firms, and the rest towards services (ECLAC 2001). However, there has also been a considerable decline in the provision of public goods by governments, and this has affected domestic industry (and particularly smaller firms), which has relied on the provision of these facilities (Reinhardt and Peres 2000). Furthermore, the state's involvement has also been reduced in planning.

In sum, while the change in policy orientation and the subsequent privatisation of state-owned enterprises has reduced the interventionist role of governments, their role as market facilitator and provider of complementary created asset-based location-specific advantages has become more critical (Dunning 1997, Stopford 1997). The lessons from East Asian economies, if anything, is not that the role of governments needs to be minimised, but that it needs to be judiciously and selectively applied (see e.g., Amden 1989, Wade 1990). 
Governments play several important roles. The work of Lall (see for instance 1996, 1997a, 1997b, 2002) points to the need of a holistic approach to selecting and leveraging sectors for dynamic growth, for stable governments, transparent policies, and the provision of basic infrastructure and skills. The provision of certain basic location advantages is perhaps most significant to note, especially for pre-catching up and catching-up economies, where firms (foreign and domestic) rely on governments to make available public and quasi-public goods. First, they have a passive role in developing the appropriate public and quasi-public goods that are the background to economic activity. As countries reach a threshold level of technological capabilities and become catching-up economies in earnest, governments need to provide more active support through macro-organisational policies. This implies developing and fostering specific industries and technological trajectories, such that the location advantages they offer are less 'generic' and more specific, highly immobile and such that they encourage mobile investments to be locked into these assets. In other words, their role as market facilitator and provider of complementary created asset-based location-specific advantages has become more critical (Dunning 1997, Stopford 1997).

Another fundamental lesson from the Asian miracle countries tends to be lost amidst the focus on openness. Much of East Asia has enjoyed considerable stability in economic policy, and this has much to do with political stability. Political stability implies long term continuance of economic policy. As Freeman and Lindauer (1999: 20) note (for the case of Africa, but which applies equally to Latin America),

'The reason returns to schooling are low..., that capital flight is high and the shift towards free trade has not created growth miracles is that schooling, investment and trade operate successfully only in a peaceful, stable environment for economic activity'.

In other words, it has not necessarily been strong regulation that has detracted the development of domestic industry but the lack of consistent regulation ${ }^{7}$.

I do not intend to analyse the differences in government intervention between East Asia and Latin America in great detail here; this has been examined in considerable detail by specialised works on individual countries collectively and singly (see e.g., Rasiah 1995, Amsden 1989, 2001, Wong 2002, Lall e.g., 1996). The basic point that all these studies raise are these: technological capacity is central to creating a domestic industrial capacity, and that

\footnotetext{
${ }^{7}$ See also Rodrik (1999)
} 
the processes underlying this are complex, slow and need careful nurturing. Knowledge may be available through markets, selecting the appropriate technologies and trajectories cannot be left solely to market forces. Furthermore, not all knowledge domains can be acquired through markets, either because appropriate markets are thin, or because internalisation and efficient utilisation are achieved only through learning-by-doing. In other cases, certain knowledge domains are more difficult to acquire and efficiently internalise than others, and require complementary non-firm assets if they are to be useful.

The NEM de-emphasises these issues. Knowledge acquisition is left to market forces, as is the structure of industry. Knowledge transfer is largely assumed to flow through the mechanisms of MNE activity. These are rather nuanced but potentially serious misconceptions, which the next section will seek to clarify.

\subsection{Technology and industrial development: the limitations of FDI as a driver}

Although it may seem that there has been a fundamental shift in the principles of industrial development, the view that technological development and upgrading is central to growth has not changed in more than 200 years, predating Schumpeter and Marx ${ }^{8}$. Indeed, the concept that knowledge is easily transferable and is available through efficient markets is rather new, and forms the basis of the new orthodoxy reflected in the NEM. As Reinhardt and Peres (2000: 1546-7) note,

"...supporters of the NEM generally pay little explicit attention to the long run dynamic consequences of the new productive structure. In particular, there is little consideration of the potential impact of on the accumulation of knowledge and technological capabilities, factors crucial in to sustained competitiveness in the new global economy. There is a tacit presumption that the new productive structure, because it rewards efficiency, will lead to a rapid process of 'learningby-doing' and therefore an expanded endowment of skills and technological capabilities. Presumably relative endowments of capital, skill and technology will change each country's comparative advantage towards higher value added products."

Technology (used here as a synonym for knowledge) is cumulative in nature and occurs on a firm-level basis. Technological capabilities are developed by the gradual accumulation of skills, information and technological effort, and firms will develop their technological capabilities in response to market, supply and demand conditions, as well as from adapting and imitating other firms in the same or similar markets. Firms are boundedly rational, and prefer to engage in innovatory activities that minimise uncertainty of the

\footnotetext{
${ }^{8}$ See Chang (2002) for a lively (and somewhat provocative) discussion.
} 
outcome. Therefore, innovations tend to be related to its existing technological competences. Given this tendency, technology is said to be path-dependent, in that current technological competences are a function of its past technological competences.

Furthermore, technology is localised in nature, not only at a firm-level because of its path dependency, but also on a country-specific basis, since cooperation between users and producers in the innovatory process is often specific to a given location, and every location has different supply and demand conditions. In addition, technology has a partly public good nature: although it is relatively less costly to acquire technology than to create it, because of its localised nature and its specificity to the innovating firm, there are costs associated for the recipient firm to efficiently utilise it in its own environment. In other words, technology is only partially appropriable by other firms, and the extent to which they can do so depends on the similarity of their environments and past technological capabilities.

It is increasingly acknowledged that technological capabilities of firms (and on an aggregated level those of countries) define the competitiveness of firms in any given industry. Technological capabilities include not only the ability to search and select the most appropriate technology to be assimilated from existing ones available- what is normally referred to as absorptive capacity- but also the creation of new knowledge through investment in $\mathrm{R} \& \mathrm{D}$.

These assets can be acquired by several means: through licensing; by indigenous development; and through the modality of FDI. Import-substituting programmes in most countries have sought to combine arms-length technology imports with indigenous development (e.g., Korea ${ }^{9}$, India), while others sought to combine indigenous development with FDI inflows (Taiwan, China, Thailand). In a globalising world it seems clear that there are potentially multiple and parallel opportunities for knowledge generation, learning and technological accumulation. This is because learning can occur through a variety of organisational means (both intra-firm and inter-firm). However, it bears repeating that learning and technological accumulation is not costless or instantaneous. Developing and sustaining a technological or a competitive advantage is slow, reversible and highly uncertain (Narula 2002a). Likewise, capital can be acquired through other means than FDI. However, although inward FDI does not represent the only option available to developing countries,

\footnotetext{
${ }^{9}$ Although strictly speaking Korea minimised the participation of MNEs through FDI in their industrial development programme, their development strategy was inherently MNE-dependent, since technologies were made available by MNEs in many instances, and were largely dependent on being integrated into the global production networks of these MNEs.
} 
given their urgency and limited resources it may represent the most efficient option (Narula and Dunning 2000). This is for at least four reasons. First, the costs of acquiring technological and organisational know-how through arms-length means is an expensive undertaking, and given the shortage of capital this option is not open to many developing country governments with limited resources. Second, liberalised markets means that firms, ceteris paribus, are likely to be more eager to maintain control of their assets and internalise the market for themselves, either through wholly owned subsidiary or in a joint venture. Exceptions exist, but only where either some strategic reason for the MNE allow for this, the host country has a strong bargaining position ${ }^{10}$, or where the technology has reached the status of a commodity. Third, infant industry protection is de rigeur in creating a domestic sector from scratch, and protected markets are a limited option within the framework of the NEM. Fourth, the resources, complementary clusters and assets necessary to support a viable and strong domestic sector are also capital and knowledge intensive.

Thus, FDI is nowadays regarded as a primary - and explicit - means by which growth can be promoted, that the availability of foreign capital and technology is an important means for economic catch-up. It is not, however, a sine qua non for development, an idea implicit in the Washington consensus, which largely speaking still holds to the view that markets for knowledge are efficient, and thus that FDI is the same thing as technology imports (with the bonus of including capital flows), and that these technological imports will generate positive externalities and spillovers to domestic firms.

\section{***TABLE 4 ABOUT HERE***}

FDI flows to Latin America have increased over the last decade as table 4 shows. The share of total global FDI stocks to most of the region has increased. Average annual growth rate of the regional as a whole is a healthy $42 \%$, greater than the equivalent rate toward Asia of $29.8 \%$. Brazil and Argentina in particular have seen rapid and increasing MNE activity. However, as noted earlier, a large share of this represents the effect of privatisation and the M\&A of these formerly state-owned assets by MNEs. From a national perspective, inflows from privatisation represent a single, one-off phenomenon - MNE acquisitions through privatisation schemes may initially generate a large initial infusion of capital, but subsequent inflows are by no means guaranteed. Indeed, in many cases state-owned companies that have been most attractive to FDI have often been the more efficient ones, requiring relatively little in the way of upgrading. It should be noted that a majority of privatisations are in the services

\footnotetext{
${ }^{10}$ For instance, where the local market is large and the MNE can only get access to other sectors in exchange for technology, or lucrative turn-key or other sub-contracts are included.
} 
sector. Furthermore, because MNEs intend to generate some rents from these investments, the net inflows can be expected to be significantly smaller in subsequent years. As such, the net effect on the economy is possibly neutral, and FDI represents simply a redistribution of assets from domestic to foreign capitalists or from the state to foreign firms ${ }^{11}$.

It is worth noting that FDI does not automatically lead to positive externalities. Furthermore, it is important to realise that MNEs are not in the business of economic development. Even where they do seek to transfer knowledge, they prefer to use technologies that are suited (first and foremost) to their own needs, and the purposes for which they have made the investment. MNEs do not make available their proprietary assets available at the whims of governments; rather they tailor their investment decisions to the existing market needs, and the relative quality of location advantages (especially skills and capabilities that the domestic economy has a comparative advantage in (Lall 2002: 17). Once the decision to enter a given market through FDI is taken, the kinds of activity and the level of competence of the subsidiary are also co-determined by the nature of the location advantages of the host location. That is to say, while MNE internal factors such as their internationalization strategy, the role of the new location in their global portfolio of subsidiaries, and the motivation of their investment are pivotal in the structure of their investment, they are dependent on the available location-specific resources which can be used for that purpose. Even if a host location does not have a large domestic market, for instance, an MNE may still engage in local production because of import restrictions. Likewise, weak intellectual property rights protection may limit an MNE's involvement in R\&D in a host location that may otherwise be an attractive location for R\&D. The point here is that even at the initial investment stage, the scope of activities undertaken in a host location is tempered by the location characteristics. These include all aspects of industrial and investment policy, which can determine the kinds of incentives provided by the host country, as well as more 'traditional' location advantages such as market size, agglomeration economies, infrastructure and asset availability.

The host country's location advantages play an important role in determining the level of competence of the subsidiary (Benito et al 2002), and this is the primary determinant of the quality of the FDI. This is for two reasons. First, the level of competence is a function of the quality of the location advantages that the host location can provide. High competence levels require complementary assets that are non-generic in nature, and are often associated with agglomeration effects, clusters, and the presence of highly specialized skills. In other words,

\footnotetext{
${ }^{11}$ Much of the state-owned assets acquired by MNEs are in services and infrastructure. It needs to be acknowledged that such investments have an important welfare effect.
} 
firms are constrained in their choice of high competence subsidiaries by resource availability. For instance, $R \& D$ activities tend to be concentrated in a few locations because the appropriate specialized resources are associated with a few specific locations. Second, MNEs have been shown to prefer to engage in sequential investment in locations that provide suboptimal returns but with which they have prior experience, because firms are known to be boundedly rational. Furthermore, while the scope of activities undertaken by a subsidiary can be modified more or less instantly, developing competence levels takes time. MNE investments in high value-added activities (often associated with high competence levels) have the tendency to be 'sticky'. Such subsidiaries tend to be embedded with the local milieu in terms of linkages with suppliers, customers and domestic institutions. The linkages are both formal and informal, and will probably have taken years - if not decades - to create and sustain. Firms generally dislike radical change, and will prefer to maintain the status quo if it does not endanger their competitiveness. When an MNE chooses to exit, it must suffer the costs of entry in another location (in terms of effort, capital and time), and these costs are nontrivial (Narula 2002b). Thus, where the level of competence of the subsidiary is high, they are more likely to maintain the subsidiary, even where an alternative location may provide a better fit to their overall strategy. It is important, also, to realise that MNEs have a wide variety of operations in a variety of countries and locations. The headquarters of an MNE has a critical role within its network of subsidiaries, adding value through contributing its own expertise as well as by coordinating the flow of knowledge within the network.

\section{***FIGURE 1 ABOUT HERE***}

It is important to emphasise that the availability of foreign-owned capital (either portfolio or direct) for developing countries is not at issue here. There have been capital flows of both kinds to viable projects to Latin America, particularly in extractive industries, and through privatisation programmes. Indeed, as Figure 1 shows, the share of the primary sector in total FDI stocks in the region have increased from 9.6\% to 12\% between 1988 and 1999. While FDI in the manufacturing sector has increased in absolute terms, the share of total global FDI stock in the secondary sector located in Latin America has declined from $7.2 \%$ to 4.2\% between 1988 and 1999. As Figure 2 shows, the share of global FDI stocks by sector located in Latin America increased only in the mining sector, food and beverages and precision instruments. With the exception of precision instruments ${ }^{12}$, the rest of these sectors are low value-adding, labour intensive activities. Such activities do not, in general, provide

\footnotetext{
12 The stock value in this sector was US\$239 million in 1999, and probably represents a single investment.
} 
much opportunity for technological spillovers and beneficial externalities. In other words, it is not FDI activities that are hard to attract, but certain kinds of FDI.

\section{***FIGURE 2 ABOUT HERE***}

The lesson I am trying to emphasise is this: FDI inflows are not a guarantee of growth. FDI and economic development are highly correlated phenomena, but both are strongly dependent on the specific resources, institutions, economic structure, political ideologies and social and cultural fabric of countries. The kind of FDI activity a country might attract (or wish to attract), too, at different stages of development, are different (Dunning and Narula 1996, Narula 1996, Narula and Dunning 2000). The motive of the investment is crucial in determining the extent to which linkages and externalities develop.

It is generally acknowledged that there are four main motives for investment: to seek natural resources; to seek new markets; to restructure existing foreign production through rationalisation, and to seek strategically related created assets. In general, less developed countries are unlikely to attract much asset-augmenting FDI. Such investment is primarily an activity undertaken in pre-frontier sharing stage and upwards (Table 2). While there has been an increase in the location of asset-augmentation activity in some developing countries during the last decade, this continues to be the exception rather than the rule. This is simply because the human resources, technological capabilities and organisational skills that these countries (or their firms) possess, tend to be in relatively low-technology and natural resource intensive sectors which have become 'generic' over time (Dunning et al 1998). Indeed, it is often the case that developing country MNEs locate subsidiaries in major clusters of activity in locations in industrialised countries in order to augment their own ownership advantages. There are exceptions to this generalisation, for instance, where a MNE has established a location as a regional centre (such as Unilever's use of Thailand as a specialist regional R\&D centre for personal products) or in rare cases, where immobile locational advantages is in the form of a cluster of highly skilled but relatively inexpensive labour that helps complement the intellectual capital and markets of MNEs, as in the case of Bangalore in India for the design of software.

\section{Resource seeking FDI}

Resource seeking FDI is a case where existing national technological assets and knowledge infrastructure do not play a significant role in determining FDI inflows. Where a region or country possesses an absolute advantage in a given scarce resource, it is in a strong position to extract rent from the MNE, despite the absence of infrastructure or a domestic 
sector. Where the resource sought is a natural one, the marginal cost of its extraction to both parties is close to zero. As such, the location is able to generate economic rent depending on the resource's rarity and accessibility in other locations. Most other resources, where the advantage is a comparative one, do not maintain a steadily low marginal cost to governments. The cost of utilising such resources rises relative to other locations as it moves to higher levels of development. The case of unskilled labour is one example. The location of labour intensive production becomes steadily less attractive to an MNE as the costs of this input rise, particularly so where productivity improvements fail to match wage cost increases. The leverage in such cases lies increasingly with the MNE, as cross-market liberalisation may enable numerous other locations in several countries to offer similar 'generic' and (easily) replicable L advantages (McIntyre et al 1996).

Resource-seeking investment generally (but not always) implies low-value adding activity and low capital expenditure on plant and equipment (extractive industries being the exception), FDI is less 'sticky', i.e., more footloose. A purely resource-seeking investment is not normally tightly integrated into the investing firm's organisational structure: indeed MNEs rarely engage in complete internalisation of raw material markets; they prefer instead to conclude non-equity agreements with foreign firms, or purchase their inputs at arms-length prices.

In general, FDI in LDCs (pre-catching-up stage) is often almost entirely resource seeking (Table 2). Since there are few other L advantages to offer MNEs, this is often the only kind of FDI present. Where vertical forward integration and further value adding does occur, either to exploit markets or to access other L advantages, the 'stickiness' of the investment increases. Both market-seeking and efficiency seeking investment imply higher integration within the MNE, and a higher level of commitment as well as a higher degree of embedment. Due to the liberalisation and deregulation associated with the NEM, a considerable portion of the investment in primary sector has been resource seeking in nature, particularly in countries such as Venezuela Columbia, Argentina and Peru (Mortimore 2000), as illustrated in Table 5.

\section{****TABLE 5 ABOUT HERE****}

\section{Market-seeking FDI}

Market seeking FDI only gains prominence in situations where the local or adjacent markets provide access to significant opportunities to achieve production economies of scale. This requires not only a sizeable population, but also the ability of the market to support 
(within a reasonable time frame) the expected demand on which the investment is based. In addition though, there is often a 'follow-the-leader' strategic response by other firms, whereby a market that might have supported two or three competitors is inundated with a larger number of new entrants than the market can efficiently support. The case of both the Chinese and the Indian automobile market represent examples of such a scenario, where despite the potential for high demand levels, few participants are actually able to make a profit. This is not the case with all sectors - investments in food and personal products for instance are much more likely to achieve economies of scale, since these products have a relatively low income elasticity of demand. Indeed, the automobile industry represents a special case in many developing countries, for what is now described as aggressive marketseeking investments in developing countries in many cases began life as defensive importsubstituting investments. These were only permitted under certain stringent conditions, but the MNE normally expected to have access to a captive protected market in return. Much of the original FDI into Latin America prior during the ISI period was primarily of this nature. Market seeking investments are the primary motive behind much of the investment in chemicals in Brazil, as well as the agro-industry in Argentina, Brazil and Mexico. The deregulation of the services sector has resulted in rapid growth in FDI in financial services, energy and telecommunications (table 5).

Market seeking FDI, by it nature, is based on a single central locational advantage. Its presence or absence is stage-dependent, but is essentially an exogenous event, with one exception. Membership of a free trade area allows countries that have small domestic markets to expand their de facto market size. In such situations, however, several formerly sovereign markets become integrated, and the choice of location then rests on other location advantages. To some extent, the establishment of MERCOSUR has resulted in some redistribution of FDI within the MERCOSUR countries, but largely speaking, it remains market seeking in nature.

\section{Efficiency seeking and strategic asset-seeking FDI}

These two types of investment are similar in that they both normally require a certain threshold level of created assets, and are generally regarded as being associated with the process of globalisation. It is no surprise that they are generally associated with countries at middle-income and industrialising countries, and in the case of asset-seeking FDI, with the industrialised countries.

As such, efficiency seeking investment in the least developed countries is an ambiguous concept, although, for many years, MNEs have engaged in export-oriented 
resource-seeking investment, which is de facto efficiency-seeking FDI. Moreover, efficiency investment - in the sense that different aspects of manufacturing activity are located in particular locations to exploit the economies of cross-border specialisation and the uneven distribution of immobile created assets- is a relatively new phenomenon. In addition, efficiency seeking investment is associated with particular sectors with particular characteristics. These sectors are those dominated by firms which have integrated global networks which are highly dependent on cost-minimisation on a global basis. That is, they seek to maintain their cost competitiveness by breaking up the value chain so as to locate production to seek the most efficient location and thereby the lowest overall cost. Such industries include apparel, electronics and automobiles (See Sturgeon and Lester 2002, Humphrey et al 1998).

In both of these types of investments, the role of sub-national clusters and the agglomeration of related activities is significant. The externalities available to countries that are home to centres of agglomeration, or possess the necessary science and technology infrastructure necessary to attract asset-augmenting FDI, are considerably different from countries which primarily attract asset-exploiting FDI. It should be noted that even where centres of excellence or agglomeration exist in a given industry, this does not imply that further knowledge intensive investments will be attracted to the same location by virtue of a single cluster existing, unless clear spillovers or externalities exist. Nonetheless, countries that have (the basis for) agglomerative economies are the ones likely to receive such FDI. This was originally the case for export processing zones (EPZs). It now applies to higher value adding activities - even in intermediate countries such as India- but only where such location advantages are perceived by MNEs to efficiently complement their own core competences.

There are three sectors that have benefited from increased FDI flows due to an efficiency-seeing motive on the part of MNEs in the NEM namely, apparel, automobiles and electronics (Table 5) (Mortimore 2000). Mexico has perhaps been the greatest beneficiary, due largely (if not wholly) to its membership of NAFTA. US MNEs have relocated much of the lower value adding activities to Mexico in automobiles, electronics and apparel. Likewise, the Caribbean basin countries, due to special access to the US market as well as the Caribbean basin initiative, have also benefited from US firms seeking to achieve efficiency in the face of increased competition from Asian firms. Mortimore (2000) argues persuasively that these activities have resulted in creating export platforms for the MNEs, with limited benefits for the host countries involved (for a more in-depth discussion, see ECLAC 2001). 
The automobile sector in Brazil is also increasingly integrated into the global production networks of MNEs. Brazil invested heavily in promoting domestic capability in the automobile sector during the ISI period, particularly towards promoting domestic suppliers and value of local content by the foreign-owned MNEs which had dominated the auto sector. With liberalisation, many of the domestic suppliers have been integrated into the global production networks (either independently or having been acquired by MNEs themselves) as the Brazilian subsidiaries of these MNEs have themselves been re-integrated into their global efficiency seeking structure (Humphrey et al 1998).

It is important to note that many of the smaller and less efficient automobile component suppliers in Brazil have been unable to survive the transition to liberalised markets and global competition. But Brazilian domestic firms have weathered the transition better than many other domestic firms from less successful former import-substitutors. Complete liberalisation and the unrestricted flow of FDI has potentially negative effects for a developing country without the appropriately endowed domestic sector. Liberalisation does indeed allow for a more efficient use of a country's resources. However, it remains a basic objective of most country's industrial policy to build up a competitive domestic sector. The indiscriminate FDI policies of most developing countries has resulted in a crowding-out of domestic investment (Agosin and Mayer 2000). Thus, liberalisation and the free flow of inward FDI can result in an FDI-dominated economy, with limited opportunity for domestic industry growth, particularly in least developed countries. From a purely economic efficiency perspective it may well be the case that FDI is pareto-optimal: FDI-dominated production is certainly better than no production at all (Narula 2002c).

\subsection{The development of the domestic sector: sustaining absorptive capacity}

It seems rather facile to highlight this, but for an FDI-assisted development strategy there needs to be an appropriate complementary domestic sector to support the FDI, and secondly, their need to be domestic firms with the capacity to learn from the MNEs. To paraphrase Lall (2002), an MNC dependent export strategy needs a proactive element for dynamic competitiveness. Indeed, the presence and condition of the domestic sector is crucial. If no domestic sector were to exist (say, in an LDC) there can no opportunity to absorb spillovers from FDI: In a perfectly liberalised world, MNEs have no incentive to encourage the development of domestic firms in (say) an LDC to meet their needs because other MNEs may 
be able to do so more efficiently, either through imports or FDI. In an extreme case, there may actually be no FDI inflow, because MNEs will prefer to locate production in a regionally optimal location, and simply import. Thus, FDI in a completely liberalised milieu does not necessarily lead to growth in the domestic sector. The benefits of FDI only occur when there is domestic investment, and where the domestic investment has the ability to internalise the externalities from FDI.

The lesson for Latin American economies derives from the need to invest in absorptive capacity. It is a necessary condition for MNE-assisted economic upgrading that a domestic sector exist which is capable of taking advantage of the linkages and spillovers that derive from MNEs. A second necessary condition is that the domestic sector (whether firm or non-firm) possess the necessary skills and competence to maximise the internalisation of the opportunities that become available through spillovers and linkages. In other words, firms must possess the necessary absorptive capacity. Absorptive capacity is about the ability to absorb available knowledge (Cohen and Levinthal 1989), and on an aggregate level, it represent define national absorptive capacity as "the ability to learn and implement the technologies and associated practices of already developed countries" (Dahlman and Nelson 1995).

Absorptive capacity supports further accumulation of technological knowledge, and technological advances support the further development of absorptive capacity in a cumulative, interactive and virtuous process during the catching-up stage. However, this virtuous circle of technological accumulation takes place only if an "adequate" minimum level of absorptive capacity is initially present. This threshold level of absorptive capacity is most significantly associated with the development of what Rasiah (2002) terms 'basic infrastructure', which represent 'generic' location advantages. Acquiring and sustaining this threshold level of absorptive capacity occurs in the 'pre-catching-up' stage (Criscuolo and Narula 2002). In this respect much of Latin America does quite well, as Table 6 shows. I have included only one indicator (telephone lines per 1000 inhabitants), and Latin America compares quite favourably with much of Asia.

\section{***Table 6 ABOUT HERE***}

However, progress towards more technology-intensive manufacturing activities depends on the existence of 'high tech infrastructure' (Rasiah 2002). This type of infrastructure is key if firms are to be able to internalise and absorb externally generated technologies, and to create their own. Such infrastructure plays an important role in promoting the innovatory and absorptive capacity of firms. It also acts as a mechanism to 
'direct' technology strategy and as a mechanism to overcome market failure. It is important to understand that while learning and absorption takes place at the firm level, but the success or failure of individual firms occurs in orchestration with an entire 'system'. Within any system, there exists a broader non-firm-specific knowledge base within what might best be described as 'non-firm actors' that are crucial to a country-level understanding of the process of technological accumulation. Non-firm actors determine the knowledge infrastructure that supplements and supports firm-specific innovation. I define 'knowledge infrastructure' in the sense proposed by Smith (1997) as being 'generic, multi-user and indivisible' and consisting of public research institutes, universities, organisations for standards, intellectual property protection, etc that enables and promotes science and technology development. They account for a certain portion of the stock of knowledge at the national level which may be regarded as 'general knowledge' in the sense that it has characteristics of a public good, and potentially available to all firms that seek to internalise it for rent generation. Thus, it is possible to speak of national technological or competitive advantages, which is not simply the sum of the firms, but the synergistic effect of all these players within a given industry within boundaries of a de facto region or country (Criscuolo and Narula 2002).

Absorptive capacity is also about the creation of the appropriate quality and quantity of human capital. However, while human capital represents a core aspect of absorptive capacity, its presence per se is not a sine qua non for knowledge accumulation. Human capital represents a subset of absorptive capabilities. While both physical and human capital are necessary inputs for catching-up, the lack of appropriate incentives for production and investment can compromise the success of the technological upgrading (Lall, 1992). Table 6 gives details of the number of tertiary -level students in several of the countries, and while there is considerable variation, Latin America performs well in this respect too. The availability of a large stock of suitably qualified workers does not in itself result in efficient absorption of knowledge. This requires the presence of institutions and economic actors within industry which defines the stock of knowledge in a given location, and the efficient use of markets and hierarchies, be they intra-firm, intra-industry or intra-country. This knowledge is not costless, and must be accumulated over time. Important externalities arise which impinge on the ease of diffusion and efficiency of absorption and utilisation of external knowledge.

Absorptive capacity is therefore also concerned with the efficient use of knowledge acquired. Firms need the ability to use prior knowledge in the solution of practical problems that are commercially viable. Thus, absorptive capacity implies problem-solving 
skills that emerge directly as a result of attempts to assimilate external knowledge. These efforts represent a potential for learning how to undertake different activities through investing in $\mathrm{R} \& \mathrm{D}$, i.e. to create new knowledge, and is referred to as the process of 'learning to learn'. Absorptive capacity accumulates only if an effort to internalise the external knowledge is exerted and in particular if the prior-knowledge has been applied to the solution of problems. Table 6 gives details of the Business expenditures in R\&D (BERD) as a percentage of GDP. Much of Latin America woefully under performs in this respect with the exception of Brazil. Table 7 gives data on US patent applications, which indicates that while patenting activity by domestic firms in Latin America (particularly Argentina, Brazil, Venezuela and Mexico) prior to NEM, was considerably lower than Korea and Taiwan, it was on par with the second-tier Asian economies. Since liberalisation, however, levels of patenting have not kept pace with Asia.

\section{***TABLE 7 ABOUT HERE***}

An important point that is often lost to policy makers is that absorption is not purely about imitation. Firms cannot absorb outside knowledge unless they invest in their own R\&D, because it can be highly specific to the originating firm and be partly tacit in nature. In addition, absorptive capacity is assumed to be a function of firm's R\&D efforts, as well as the degree to which outside knowledge corresponds to the firm's needs, and the general complexity of external knowledge.

Absorptive capacity is not constant along the converging path: it evolves with the level of technological development (Criscuolo and Narula 2002). Different countries at different distances from the frontier acquire and assimilate technological spillovers using different modalities. During the catching-up phase, absorptive capacity is predominately directed at assimilating spillovers originated from trade and/or inward FDI. This strategy was fundamental to the rapid growth of the Asian newly industrialising economies during the 1970s and 1980s, and countries such as Malaysia and China more recently. At the prefrontier-sharing phase (as well as at the frontier) increases in the knowledge base occur primarily through an active engagement in accessing to foreign located technological spillovers, through outward FDI-related R\&D, joint ventures and strategic alliances. This has been the strategy of the Asian NICs since the 1990s.

As they approach the frontier, countries must have the capacity not just to absorb and imitate technological development created by others, but also the ability to generate inventions of their own. This requires technological capabilities that are non-imitative. In other words, learning-by-doing and learning-by-using have decreasing returns as one 
approaches the frontier, and in-house learning and learning-by-alliances become more efficient options. The case of Korea (Amsden 1989, Kim 1995, Sachwald 2001) illustrates the evolution of the ability to assimilate $\mathrm{R} \& \mathrm{D}$ spillovers during the catching-up process. Korea relied on technology licensing and imports of capital goods from developed countries in acquiring external knowledge till the 1980s, but this enabled it only to access second-best practice technologies. Korea is at the pre-frontier sharing or frontier-haring phase in several sectors. Its domestic technological capabilities (inter alia deriving from its education system) are however geared towards absorption through imitation rather than in-house learning (see Kim 1995, Suh 2000). In addition, the difficulty of further assimilation connected to the more tacit nature of advanced knowledge and the reluctance of industrialised countries to transfer technology to Korean firms for fear of losing their technological advantage has aggravated this process. There is now an increasing emphasis technological capability building and on reverse technology transfer, that is, through outward FDI by Korean MNEs (Sachwald 2001, Lee 2001).

\subsection{The importance of promoting FDI and domestic capacity concurrently.}

It is true that the determinants of economic development are similar to the determinants of FDI, but this does not mean that there is a simple cause and effect between them. Particular types of FDI tend to be attracted to countries with certain levels of economic development and appropriate economic structures. But simply to 'pump' a country full of FDI will not lead to its catapulting to a higher stage of development. To assume FDI drives economic development is to assume that FDI is about capital, and that the lack of economic growth is about the lack of liquidity. The lesson from the Asian economies is that FDI and domestic capability need to be concatenated and pursued in tandem (Ozawa 1995, 1996). This, more than anything, is the lesson that can be learnt from the 'flying geese paradigm' proposed by Akamatsu and adapted to the issue of FDI by Kojima (e.g., 1990) and Ozawa (e.g., 1996).

Of course, the circumstances associated with the flying geese paradigm are somewhat unique to Asia, as well as the geo-political dynamics of that particular time period. First, Japan's acted as the driver of this process, and its own rapid upgrading required it to seek alternative locations to establish operations. Latin America did not have the benefit of such a 
driver $^{13}$. Second, the cold war and US military efforts first in Korea, and later in Vietnam helped spur demand for local manufacturing. US trade policies were also favourably disposed towards exports from many of the friendly countries in the region. Third, at the time, Latin America, Africa and much of the rest of Asia were engaged in IL-IS policies. This meant that when MNEs (whether European, US or Japanese) needed to relocate labour-intensive production and to seek to import these intermediate goods, there were just a handful of countries which had both the technological capabilities and an appropriate export-friendly orientation to do so from. In other words, MNEs had only a few choices, and this resulted in a high concentration of investment in these locations. Transferring technology to local suppliers was a very acceptable cost to MNEs, and this created a virtuous circle of technological accumulation: the better the technological capabilities of domestic firms got, the higher the local productivity and the greater the benefits to the MNEs. Fourth, these Asian economies were natural resource-poor, unlike Latin America. As I have discussed in an earlier section, MNE subsidiaries tend to display inertia in their operations. Their operations in Asia did not represent forward integration from existing local resource-seeking investments, and began from a clean slate. In the case of Japanese firms, they already had some experience with many of these Asian economies from their pre-war and wartime economic and military activities. Even where MNEs were not deterred by the IS-IL orientation, Sequential investments in Latin America sought to add value to resource based initial investments and tended to remain lowvalue adding. Fifth (but somewhat related to the last point) that the East Asian countries focused on developing electronics and transport equipment sectors was somewhat serendipitous.

The process of development and the role of FDI varies between countries and industries because of the various economic and industrial policy options selected. Industrial policy where certain industries are selected for rapid growth by focused investments through intensive development of created assets can and do accelerate economic development. The examples of both the more advanced industrialised countries (such as the NICs) and the second tier emerging economies, particularly Malaysia and Brazil illustrate this. Attracting specialised FDI to a particular sector can alter the sequence of industrial upgrading (Williamson and $\mathrm{Hu}$ 1994), because specialised FDI may help improve the created assets associated within a sector (say consumer electronics production). Created assets in this one

\footnotetext{
${ }^{13}$ Reinhardt and Peres (2000) argue that a clear distinction can be made between countries north and south of Panama along the same lines: Countries North of Panama have the advantage of geographical proximity to the US, and US policies have actively promoted trade and investment with these countries.
} 
sector may have significant knowledge flows externalities in another (say micro-electronics design), which in turn may represent significant input to another sector (say software development). But this assumes the presence of a virtuous circle, and the development of appropriate clusters.

FDI-assisted growth requires the capacity to be a 'strategic follower' (Ramos 2000). This requires a systematic understanding of what technological capabilities need to be developed or enhanced, and to seek to actively coordinate potential users with sources of the appropriate technologies. Asian governments that pursued an autonomous strategy actively sought to identify, acquire and transfer technologies, with government agencies acting as market-makers. Left to their own means, firms have a tendency to be risk averse, and to avoid the financial and technological risk of upgrading their technological assets as long as these provide a reasonable rate of return. This short-term myopia is not unique to Latin American firms: governments in Asia - and particularly in Japan, Korea and Taiwan - sought to overcome or at least reduce the perceived risk levels by providing subsidised loans and other incentives to domestic firms that restructured their existing operations by adopting new technologies in the products and processes that promoted international best practise ${ }^{14}$.

The countries with the most successful technological upgrading - Korea, Taiwan and to a lesser extent Brazil - allocated subsidies in what Amsden and Hikino (2000) and Amsden (2001) call a 'reciprocal control mechanism'. That is, incentives and subsidies whether to upgrade technologically, promote local content, expand exports or reduce import-dependence were subject to performance standards that were actively monitored, and in Amsden's (2001) words, were 'redistributive in nature and results-oriented' and acted to prevent government failure.

To be sure, upgrading of technological capabilities of domestic firms can no longer be pursued in quite the same way in a globalised world. International competition is a given, and there can be no return to the infant industry model of the IS-IL era. While Latin American countries such as Brazil had considerable investment in $R \& D$, a majority of the formal $R \& D$ efforts were conducted by state-owned enterprises and the non-firm sector. While the role of the state must necessarily remain a significant investor in innovation, these policies need to be orchestrated with the private firm sector, whether domestic or foreign.

\footnotetext{
${ }^{14}$ Ramos (2000) expands on this theme (pp 1712-3), and discusses how such programmes were also used widely in Europe as part of the Marshall plan.
} 


\subsection{Coordination failures: the inertia of transition}

There are many unique problems that derive directly from the policy volte-face that the switch from import substitution to NEM implies. The social costs of reformation, resource reallocation and structural adjustment on such a large scale resulted in considerable social unrest. Among other things, I want to highlight the inertia of institutions to successfully switch from one policy orientation to another.

Likewise Korea and Taiwan's (as is also the case with Japan) policies also evolved over 40 years, while Latin American economies have attempted to rapidly restructure since the late 1980s. This represents a rapid transition, exceeded only by the formerly centrally planned European economies.

Latin American countries find themselves in a new multilateral milieu, but one in which they have little experience. They have hitherto operated their economies on a national basis, and by looking inward they have been able to minimise exposure to external shocks. Institutions continue to remain largely independent and national. By institutions I mean the 'sets of common habits, routines, established practises, rules, or laws that regulate the interaction between individuals and groups' (Edquist and Johnson 1997). Institutions create the milieu within which economic activity is undertaken and establish the ground rules for interaction between the various economic actors, and represent a sort of a 'culture'. Institutions are both formal and informal, and will probably have taken years - if not decades - to create and sustain. To modify and develop institutions is a complex and slow process, particularly since they cannot be created simply by government fiat. Such change is even more complex where the new institutions require synchronisation between countries. The Triad countries have taken 50 years to adjust and reform institutions, but even here there is inertia. The EU, for instance, has failed to reform its agricultural sector. Norway remains largely mired in an import-substituting world, with a strong tendency towards central planning and state-owned economic actors (Narula 2002c).

Liberalisation is an important force in economic globalisation since it requires a multilateral view on hitherto-domestic issues and promotes interdependence of economies. It is implicit within this view that FDI and MNE activity can be undertaken with much greater ease than previously. This view is enforced because countries have explicitly sought to encourage MNE activity as a source of much-needed capital and technology. In addition to financial crises, the general warming of the attitudes towards FDI emanate from an accelerating pace of technical change and the emergence of integrated production networks of MNEs (Lall 2000). 
On the other hand, the establishment of the World Trade Organisation, and the preceding GATT rounds, which encouraged liberalisation, have in fact acted as an important force in establishing common rules and frameworks. Certainly, the various agreements within WTO have serious ramifications for member countries. In principle WTO agreements encourage an easier flow of technology and knowledge, and more alternative sources. Also, firms situated in LDCs potentially have greater (and less impeded) access to important markets such as those of the OECD countries (Lall 1997b).

Nonetheless, liberalisation (among other forces related to the Washington Consensus) has acted as a major 'shock' to the institutions within most countries, since it has introduced not just new economic actors (MNEs), but it has also required major restructuring of existing institutions (legal codes, political structures, policy orientation). Despite the view of the Washington Consensus, the exposure of these economies to the vagaries of international competition suddenly will not necessarily facilitate their institutional setting (as best illustrated by the chaotic state of the ex-soviet economies). As Kogut (2000: 34) notes:

Institutions, however, do not travel by the arteries of multinational corporations. They reflect patterns of behaviour that are inscribed in legal codes and political and economic relationships. Outside the power of any one actor to change, institutions are social agreements that guide and coordinate the interdependent acts of economic actors in a country.

\section{$\underline{4 . \text { Conclusions }}$}

Apart from the two approaches representing different ideological positions, the ISI approach adopted by Latin America and the autonomous strategy of East Asia shared many important and fundamentally important features in common. Both espoused the development of domestic industrial capacity through a concatenation of foreign technologies (through technology imports and FDI) and domestic competitiveness. Both sought to enhance absorptive capacity and promote infrastructure. Indeed, the autonomous strategy favoured by Korea and Taiwan was as much about import substitution as it was about promoting exports. The two approaches - in hindsight - also differed in several important respects. These include disagreements about the rapidity of learning, and an underestimation the costs and the difficulties of internalising technological spillovers. Perhaps most significantly, however, was the failure to implement reciprocal control mechanisms and international competition to target competitiveness against international norms, which export-orientation allowed the East Asian 
economies to do. Countries such as Brazil that targeted international markets in certain industries, did in fact achieve similar levels of technological competitiveness to the Asian countries in certain areas (Viotti 2002, Amsden 2001,). Such gains may well be dissipated in the face of rapid liberalisation, as indeed Humphrey et al (1998) seem to suggest.

The switch from ISI to NEM in Latin America does not bode well for the prospects for industrial development. While the NEM model has helped corrected many inefficiencies, inter alia, improving important macro-economic fundamentals, and reducing the excessive role of the state in domestic industrial activity, it has also led to a rapid and overzealous reduction in the state's involvement in the provision of public and quasi public goods which are necessary conditions for industrial development (Ramos 2000, Katz 2001, Alcorta and Peres 1998, Alcorta 2000).

Market forces cannot substitute for the role of governments in developing and promoting a proactive industrial policy. Firms necessarily take a shorter term, profit maximising view because they are largely risk averse. MNEs and unrestrained flows of inward FDI may well lead to an increase in productivity and exports, but they do not necessarily result in increased competitiveness of the domestic sector or increased industrial capacity, which ultimately determines economic growth in the long run. FDI per se does not provide growth opportunities unless a domestic industrial sector exists which has the necessary technological capacity to profit from the externalities from MNE activity. This is well illustrated by the inability of many Asian countries which have relied on a passive FDIdependent strategy to upgrade their industrial development. Furthermore, infant industry protection is still largely irreplaceable, since unrestrained FDI may result in 'crowding out' of the domestic sector. FDI and domestic capabilities and a domestic sector need to be concatenated and properly phased if positive results can be achieved. The lesson from East Asia is not that the role of governments should be substituted by the market, but that markets and governments can co-exist.

I should emphasise that I am not advocating a return to import substitution industrialisation in the traditional sense. Nor is this possible. Globalisation is largely irreversible, and cross-border competition does indeed help reduce inefficiencies. Nonetheless, there is no tangible developmental alternative to building up domestic capabilities. The concept of promoting catch-up through infant industry promotion has always been the bedrock of industrial development policies and catch-up (see Chang 2002 for a recent discussion). 
However, catching-up implies the absorption and mastery of existing knowledge, and this implies that there must be a body of knowledge available for imitation, and that domestic firms must have the capability to internalise these assets. Agreements within the WTO framework such as TRIPs, TRIMs and SCM severely limit the potential for developing countries to utilise traditional policy instruments, effectively reducing opportunities for domestic industrial capacity. 


\section{References}

Agosin, M. and Mayer, R., (2000) Foreign Investment in Developing Countries: Does it Crowd in Domestic Investment?, UNCTAD Discussion Papers No. 146

Alcorta, L. (2000) New Economic Policies and the Diffusion of Machine Tools in Latin America, World Development, Volume 28, pp 1657-1672

Alcorta, L. and Peres, W. (1998) Innovation systems and technological specialization in Latin America and the Caribbean, Research Policy, Vo 26, pp 857-881

Amsden, A. (1989) Asia's Next Giant, New York: Oxford University Press.

Amsden, A. (2001) The Rise of the 'The Rest', Oxford: Oxford University Press.

Amsden, A. and Hikino, T. (2000) 'The Bark is Worse than the Bite: New WTO Law and Late Industrialisation', Annals of the American Academy of Political \& Social Sciences, vol 570, pp. 104-14.

Benito, G., Grogaard, B. and Narula, R. (2002) 'Environmental Influences on MNE Subsidiary Roles: Economic Integration and the Nordic Countries', mimeo, Oslo.

Bruton, H. (1998) 'A Reconsideration of Import Substitution', Journal of Economic Literature, vol 36, pp. 90336.

Chang, Ha-Joon (2002) Kicking away the Ladder: Development Strategies in Historical Perspective, Anthem: London

Cohen, W.M. and Levinthal, D.A. (1989) 'Innovation and Learning: The Two Faces of R\&D', The Economic Journal, vol 99, pp. 569-96.

Criscuolo, P. and Narula, R. (2002) 'A Novel Approach to National Technological Accumulation and Absorptive Capacity: Aggregating Cohen and Levinthal', MERIT Research Memorandum 2002-16.

Dahlman, C. and Nelson, R. (1995) 'Social Absorption Capability, National Innovation Systems and Economic Development', in Perkins, D.H. and Koo, B.H. (eds.), Social Capability and Long-term Growth, Basingstoke: Macmillan Press.

Dunning, J.H. (1997) 'A Business Analytic Approach to Governments and Globalisation', in Dunning, J.H. (ed.), Governments, Globalisation and International Business, Oxford: Oxford University Press, pp. 114-31.

Dunning, J.H. and Narula, R. (1996) (eds), Foreign Direct Investment and Governments: Catalysts for Economic Restructuring, London: Routledge.

ECLAC (2001) Foreign Investment in the Latin American and the Caribbean 2000, United Nations, Santiago.

Edquist, C. and B. Johnson, 1997. Institutions and Organisations in Systems of Innovation, in C. Edquist ed.: Systems of Innovation: Technologies, Institutions and Organisations. Pinter: London and Washington. Freeman, R. and Lindauer, D.L. (1999) 'Why Not Africa?' NBER Working Paper No. 6942.

Hamilton, A. (1791) Report on Manufactures, reprinted in The Papers of Alexander Hamilton, by Syrett, H.C. (ed.), New York: Columbia University Press, 1966.

Hobday, M.G. (1995) Innovation in East Asia: The Challenge to Japan, Cheltenham: Edward Elgar.

Hoekman, B. (2002) 'Economic Development and the WTO after Doha', CEPR Discussion Paper Series No. 3374.

Humphrey, J., Mukherjee, A., Zilbovicius, M. and Arbix, G. (1998) 'Globalisation, FDI and the Restructuring of Supplier Networks: The Motor Car Industry in Brazil and India', in Kagami, Humphrey, J. and Piore, 
M. (eds.), Learning, Liberalisation and Economic Adjustment, Tokyo: Institute of Developing Economies.

Katz, J. (2001) 'Structural Reforms and Technological Behaviour. The Sources and Nature of Technological Change in Latin America in the 1990s', Research Policy, vol 30, pp. 1-19.

Kim, L. (1995) 'Absorptive Capacity and Industrial Growth: A Conceptual Framework and Korea's Experience', in Perkins, D.H. and Koo, B.H. (eds.), Social Capability and Long-term Growth, Basingstoke: Macmillan Press.

Kogut, B. (2000) 'The Transatlantic Exchange of Ideas and Practices: National Institutions and Diffusion', les notes de l'ifri No. 26.

Kojima, K. (1990) Japanese Direct Investment Abroad Tokyo, International Christian University.

Lall, S. (1992) 'Technological Capabilities and Industrialization', World Development, vol 2(2), pp.165-86.

Lall, S. (1996) Learning from the Asian Tigers, Macmillan: Basingstoke.

Lall, S. (1997a) 'East Asia', in Dunning, J.H. (ed.), Governments, Globalisation and International Business, Oxford: Oxford University Press, pp. 407-30.

Lall, S. (1997b) 'Policies for Industrial Competitiveness in Developing Countries: Learning from Asia', Report prepared for the Commonwealth Secretariat, Oxford.

Lall, S. (2000) 'Foreign Direct Investment and Development: Policy and Research Issues in the Emerging Context', QEH Working Paper Series 43.

Lall, S. (2002) 'Foreign Direct Investment, Technology Development \& Competitiveness: Issues and Evidence', mimeo.

Lee, K-R. (2001) 'Technological Catching-up through Overseas Direct Investment Samsung's Camera Business', in Sachwald, F. (ed.), Going Multinational. The Korean Experience of Foreign Direct Investment, London: Routledge, pp. 275-314.

List, F. (1844) The National System of Political Economy, London: Longmans, Green \& Co., 1885, reprinted by Fairfield: Augustus M. Kelley, 1977.

McIntyre, J., Narula, R. and Trevino, L. (1996) The Role of Export Processing Zones For Host Countries and Multinationals: A Mutually Beneficial Relationship? International Trade Journal, Vol 10, pp 435-466.

McIntyre, J., R. Narula and L. Trevino, 1996. The Role of Export Processing Zones for Host Countries and Multinationals: A Mutually Beneficial Relationship? International Trade Journal 10:435-466. Winter.

Mortimore, M., (2000) 'Corporate Strategies for FDI in the Context of Latin America's New Economic Model', World Development, vol (28)9, pp. 1611-26.

Narula, R. (1996) Multinational Investment and Economic Structure, Routledge, London.

Narula, R. (2002a) 'The Implications of growing Cross-border Interdependence for Systems of Innovation', MERIT-Infonomics Research Memorandum series, Number 17.

Narula, R. (2002b) 'Innovation Systems and 'Inertia' in R\&D Location: Norwegian Firms and the Role of Systemic Lock-in', Research Policy, vol 31, pp. 795-816.

Narula, R. (2002c) 'Regional Integration and the Strategies of Multinational Firms' in Trade and Regional Integration in the Development Agenda, Brookings Institution/IDB, Washington DC.

Narula, R. and Dunning, J.H. (2000) 'Industrial Development, Globalisation and Multinational Enterprises: New Realities for Developing Countries', Oxford Development Studies, vol 28(2), pp. 141-67. 
Nelson, R. and Pack, H. (1995) 'The Asian Growth Miracle and Modern Growth Theory', mimeo, Columbia University.

Ozawa, T. (1995) 'Structural Upgrading and Concatenated Integration', in Simon, D. (ed.), Corporate Strategies in the Pacific Rim: Global versus Regional Trends, London: Routledge, pp. 215-46.

Ozawa, T. (1996) 'Japan: the Macro-IDP, Meso-IDPs and the Technology Development Path (TDP)', in Dunning, J.H. and Narula, R. (eds.), Foreign Direct Investment and Governments: Catalysts for Economic Restructuring, London: Routledge, pp. 423-41.

Pack, H. (2001) 'The Role of Acquisition of Foreign Technology in Taiwanese Growth', Industrial and Corporate Change, vol 10, pp. 713-33.

Ramos, J. (2000) 'Policy Directions for the New Economic Model in Latin America', World Development, vol 28, pp. 1703-17.

Rasiah, R. (1995) Foreign Capital and Industrialization in Malaysia, London: Macmillan

Rasiah, R. (1995) Foreign Capital and Industrialization in Malaysia, London: Macmillan

Rasiah, R. (2002) 'Infrastructure and Domestic Patents in Developing Asia', mimeo, UNU/INTECH, Maastricht.

Reinhardt, N. and Peres, W. (2000) 'Latin America's New Economic Model: Micro Responses and Economic Restructuring', World Development, vol (28)9, pp. 1543-66.

Rodríguez, F. and Rodrik, D. (1999) 'Trade Policy and Economic Growth: A Skeptic's Guide to the CrossNational Evidence', NBER Working Paper No. 7081.

Rodrik, D. (1999) The new global economy and developing countries: making openness work, policy Essay No 24, Overseas Development Council, Washington, D.C.

Sachwald, F. (2001) 'Globalisation and Korea's Development Trajectory', in Sachwald, F. (ed.), Going Multinational. The Korean Experience of Foreign Direct Investment, London: Routledge, pp. 361-82.

Smith, A. (1776) The Wealth of Nations, New York: The Random House, 1937.

Smith, K. (1997) 'Economic Infrastructures and Innovation Systems', in Edquist, C. (ed.), Systems of Innovation: Technologies, Institutions and Organisations, London and Washington: Pinter.

Stopford, J. (1997) Implications for national governments, in J.H. Dunning (ed) Governments, globalisation and international business, Oxford: Oxford University Press, pp 457-480

Sturgeon, T. and Lester, R. (2002) 'Upgrading East Asian Industries: New Challenges for Local Suppliers', mimeo, Industrial Performance Center, MIT, Cambridge (MA).

Suh, J. (2000) 'Korean Innovation System: Challenges and New Policy Agenda, mimeo, Maastricht.

UNCTAD (2000) World Investment Report 2000, Geneva and New York: United Nation.

UNIDO (2002) Industrial Development Report 2002/3, Vienna: UNIDO.

Viotti, E. (2002) National Learning Systems: A new approach on technological change in late industrializing economies and evidences from the cases of Brazil and South Korea, Technological Forecasting and Social Change, Volume 69, pp 653-680

Wade, R. (1988) 'The Role of Government in Overcoming Market Failure in Taiwan, Republic of Korea and Japan', in Hughes, H. (ed.), Achieving Industrialisation in East Asia, Cambridge: Cambridge University Press.

Wade, R. (1990) Governing the Market: Economic Theory and the Role of Government in East Asian Industrialization, Princeton NJ: Princeton University Press. 
Williamson, P. and Hu, Q. (1994) Managing the Global Frontier, London: Pitman Publishing.

Wong, P.K. (2002) 'From Using to Creating Technology: The evolution of Singapore's National Innovation system and the Changing Role of Public Policy', mimeo.

World Bank (1994) The East Asian Miracle, Oxford: Oxford University Press. 
Table 1, Selected Indicators, Selected Asian and Latin American Countries, 1998

$\begin{array}{llll}\begin{array}{l}\text { GDP per capita } \\ 1998 \text { (constant 1995 US\$) }\end{array} \quad \begin{array}{ll}\text { FDlation, total net inflows } \\ \text { (sq km) }\end{array} & \begin{array}{l}\text { Industry, VA High-tech exports } \\ \text { (\% of GDP) }\end{array} & \begin{array}{l}\text { Mobile phones } \\ \text { (\%DP) (\% of mfg exports) }\end{array} & \text { (per 1,000 people) }\end{array}$

Asia

Hong Kong, Cl
Indonesia
Korea, Rep.
Malaysia
Singapore
Thailand
Vietnam
China
India
Pakistan
Sri Lanka

21801
975
11022
4380
25297
2629
330
725
431
500
789

$6645600 .$.
203678368
46430000
22180000
3923000
59793500
76520000
1242179968
979672896
131582000
18778000

..
$1,904,570.00$
$99,260.00$
$329,750.00$
620
$513,120.00$
$331,690.00$
$9,598,050.00$
$3,287,590.00$
$796,100.00$
$65,610.00$

$\begin{array}{rl} & 15.2 \\ -0.4 & 44.9 \\ 1.7 & 43.8 \\ 3 & 43.6 \\ 6.6 & 35.4 \\ 6.5 & 38.8 \\ 7.3 & 32.6 . . \\ 4.6 & 49.3 \\ 0.6 & 25.7 \\ 0.8 & 23.8 \\ 1.3 & 27.5 . .\end{array}$

21.1
10.4
27.1
54.9
59.1
34.4

15.5
5.6
0.1

476.7

5.2

301.7

101.4

281.7

32.8

2.9

19

1.2

1.6

Latin America

$\begin{array}{lrr}\text { Argentina } & 8474 & 36125000 \\ \text { Bolivia } & 972 & 7950000 \\ \text { Brazil } & 4501 & 165814784 \\ \text { Chile } & 5247 & 14821700 \\ \text { Costa Rica } & 3765 & 3526000 \\ \text { Colombia } & 2404 & 40804000 \\ \text { El Salvador } & 1727 & 6035000 \\ \text { Guatemala } & 1531 & 10799000 \\ \text { Jamaica } & 1712 & 2576000 \\ \text { Mexico } & 3540 & 95252432 \\ \text { Nicaragua } & 452 & 4794380 \\ \text { Paraguay } & 1787 & 5219000 \\ \text { Trinidad and T } & 4651 & 1285140 \\ \text { Venezuela, RE } & 3531 & 23242000\end{array}$
$2,780,400.00$
$1,098,580.00$
$8,547,400.00$
$756,630.00$
$51,100.00$
$1,138,910.00$
$21,040.00$
$108,890.00$
$10,990.00$
$1,958,200.00$
$130,000.00$
$406,750.00$
$5,130.00$
$912,050.00$
2.2
11.2
4.1
6.4
4.4
3
9.2
3.5
5.3
2.7
8.7
8.7
2.3
11.9
4.7

28.7
18.7
28.8
34.2
30.6
27
27.6
20
31.5
28.5
21.6
27
38.8
35.3

28.7

18.7
28.8

34.2

30.6

27.6

20

31.5

28.5

21.6
27

38.8

35.3

6
..
9.6
3.7
..
8.8
7.8
7.2
$1 .$.
19.3
5.4
3.9
1.4
2.6

70.1

30

46.7

65.1

28.4

45.6

17.6

10.3

30.9

35

3.9

44.4

20.5

Source: World Development Indicators, 2001 
$\underline{\text { Table 2: relating the catch-up process to motivations for FDI }}$

\section{Developing countries}

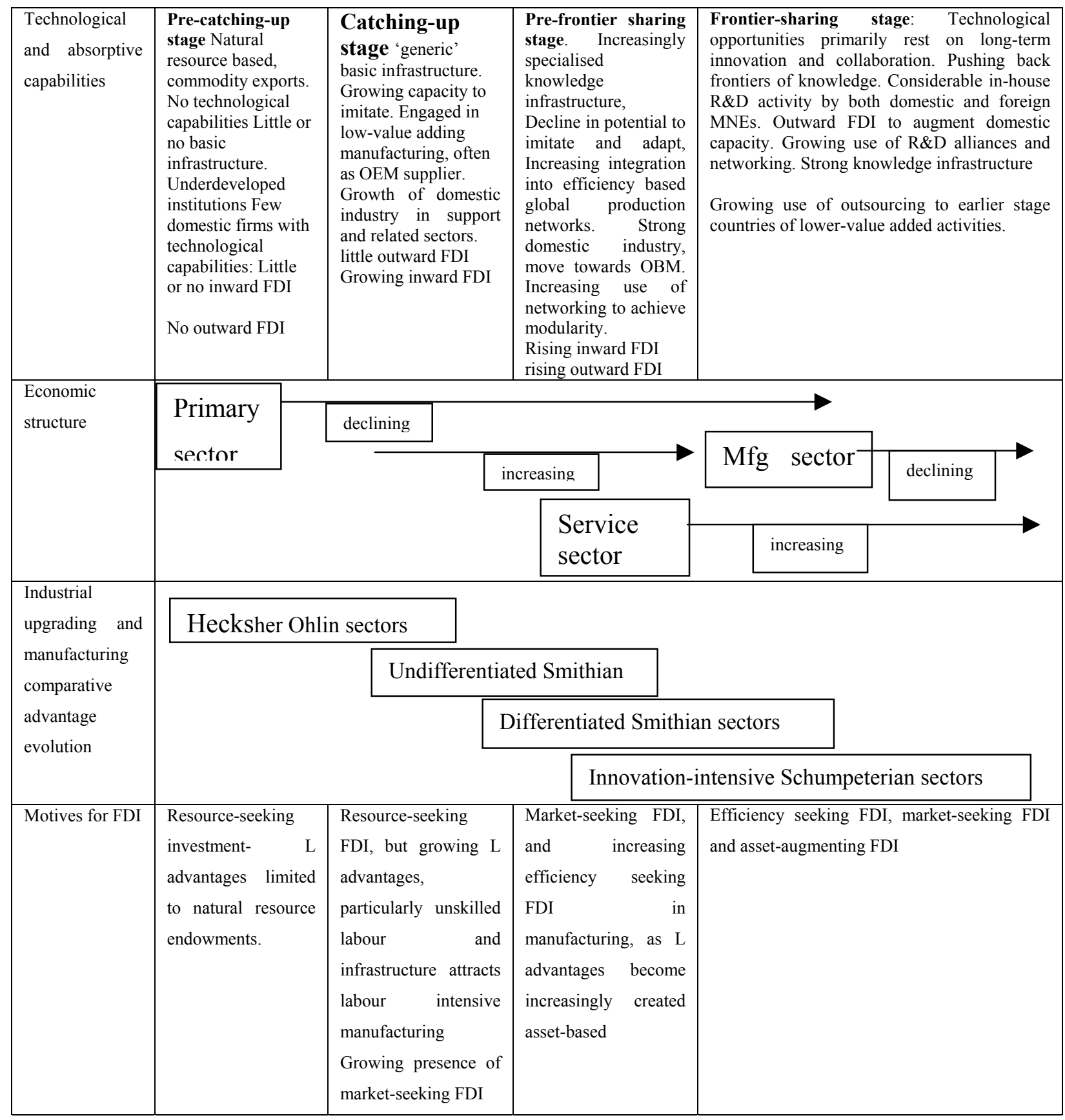


Table 3 Indicators of industrial development, pre and post-liberalsation (1985 and 1997)

\begin{tabular}{|c|c|c|c|c|c|c|c|c|c|c|}
\hline \multirow[b]{2}{*}{ Asia } & \multicolumn{2}{|c|}{ Mfg exports } & \multicolumn{2}{|c|}{$\begin{array}{l}\text { primary sector exports } \\
\text { andise exports) }\end{array}$} & \multicolumn{2}{|l|}{$\begin{array}{l}\text { mfg imports } \\
\% \text { of imports }\end{array}$} & \multicolumn{2}{|c|}{$\begin{array}{l}\text { Mfg, value added } \\
(\% \text { of GDP) }\end{array}$} & \multicolumn{2}{|c|}{$\begin{array}{l}\text { primary sector, VA } \\
(\% \text { of GDP) }\end{array}$} \\
\hline & & & & & & & & & & \\
\hline Indonesia & 13.0 & 45.0 & 87.0 & 55.0 & 72.1 & 69.1 & 15.8 & 24.1 & 42.4 & 38.4 \\
\hline Korea, Rep. & 91.3 & 91.3 & 8.7 & 8.7 & 57.2 & 61.4 & 29.0 & 30.9 & 24.1 & 17.9 \\
\hline Malaysia & 27.2 & 78.8 & 72.8 & 21.2 & 71.6 & 84.8 & 19.3 & 28.7 & 39.1 & 28.1 \\
\hline Singapore & 51.2 & 85.7 & 48.8 & 14.3 & 55.5 & 84 & 23.6 & 23.1 & 13.8 & 12.4 \\
\hline China & $\mathrm{N} / \mathrm{A}$ & 87.3 & & 12.7 &.. & 81.3 & 35.4 & 37.5 & 36.1 & 30.4 \\
\hline India & 58.1 & 76.0 & 41.9 & 24.0 & 54.4 & 53.8 & 16.5 & 15.6 & 43.6 & 39.2 \\
\hline \multirow{2}{*}{\multicolumn{3}{|c|}{$\begin{array}{lll}\text { Pakistan } & 61.9 & 83.9 \\
\text { Sri Lanka } & 32.6 \text { N/A } & \end{array}$}} & 38.1 & 16.1 & 50.7 & 55.3 & 15.9 & 15.8 & 35.1 & 35.3 \\
\hline & & & 67.4 & & $54.6 .$. & & 14.7 & 16.5 & 39.2 & 32.1 \\
\hline Chile & 6.9 & 17.3 & 93.1 & 82.7 & 64.9 & 80.7 & 16.2 & 16.4 & 29.0 & 26.2 \\
\hline Costa Rica & 22.4 & 55.7 & 77.6 & 44.3 & 70.7 & 85.5 & 25.5 & 23.5 & 29.7 & 19.8 \\
\hline Colombia & 16.9 & 32.3 & 83.1 & 67.7 & 69.5 & 79.5 & 22.0 & 14.9 & 31.0 & 26.1 \\
\hline El Salvador & 25.7 & 46.5 & 74.3 & 53.5 & 56.7 & 68.5 & 17.8 & 21.4 & 32.5 & 18.1 \\
\hline Guatemala & 20.5 & 32.8 & 79.5 & 67.2 & 52 & 76.8 & 15.8 & 13.6 & 29.7 & 29.8 \\
\hline Jamaica & 53.3 & $\mathrm{~N} / \mathrm{A}$ & 46.8 & & 46.2 &.. & 19.7 & 13.8 & 24.2 & 24.9 \\
\hline Mexico & 27.1 & 85.2 & 72.9 & 14.8 & 74.8 & 84.6 & 24.0 & 21.3 & 21.3 & 12.4 \\
\hline Nicaragua & 6.3 & 8.1 & 93.7 & 91.9 & 57.5 & 68.8 & 27.6 & 15.1 & 31.1 & 39.5 \\
\hline Paraguay & 5.5 & 13.6 & 94.5 & 86.4 & 60.3 & 70.2 & 14.2 & 15.5 & 37.3 & 35.7 \\
\hline Trinidad and Tobago & 18.2 & 43.8 & 81.8 & 56.2 & 68.8 & 71.1 & 6.8 & 8.5 & 45.6 & 29.3 \\
\hline Venezuela, RB & 10.0 & 18.5 & 90.0 & 81.5 & 76.2 & 82.1 & 21.9 & 15.4 & 26.8 & 25.0 \\
\hline \multicolumn{11}{|l|}{ regional total } \\
\hline
\end{tabular}

Source: World development Indicators CD-ROM, 2001 
Table 4: Inward FDI stock, various years

\begin{tabular}{|c|c|c|c|c|c|}
\hline \multirow[b]{2}{*}{ Total global } & \multirow{2}{*}{$\begin{array}{r}1990 \\
1888672\end{array}$} & \multirow{2}{*}{$\begin{array}{r}2000 \\
6314271\end{array}$} & \multirow{2}{*}{$\begin{array}{r}1990 \\
100\end{array}$} & \multicolumn{2}{|c|}{$\begin{aligned} \text { avg annual } \\
\text { growth rate } \\
2000 \text { 1990-2000 }\end{aligned}$} \\
\hline & & & & 100 & $23.4 \%$ \\
\hline Total LAC & 116678 & 606907 & 6.2 & 9.6 & $42.0 \%$ \\
\hline Argentina & 9085 & 73441 & 0.5 & 1.2 & $70.8 \%$ \\
\hline Bolivia & 1026 & 5574 & 0.1 & 0.1 & $44.3 \%$ \\
\hline Brazil & 37143 & 197652 & 2.0 & 3.1 & $43.2 \%$ \\
\hline Chile & 10067 & 42933 & 0.5 & 0.7 & $32.6 \%$ \\
\hline Colombia & 3500 & 19682 & 0.2 & 0.3 & $46.2 \%$ \\
\hline Ecuador & 1626 & 6796 & 0.1 & 0.1 & $31.8 \%$ \\
\hline Paraguay & 396 & 1756 & 0.0 & 0.0 & $34.4 \%$ \\
\hline Peru & 1330 & 9900 & 0.1 & 0.2 & $64.4 \%$ \\
\hline Uruguay & 1007 & 2300 & 0.1 & 0.0 & $12.8 \%$ \\
\hline Venezuela & 2260 & 25846 & 0.1 & 0.4 & $104.4 \%$ \\
\hline Total above & 67440 & 385879 & 3.6 & 6.1 & $47.2 \%$ \\
\hline Mexico & 22424 & 91222 & 1.2 & 1.4 & $30.7 \%$ \\
\hline South, East anc & 297282 & 1183952 & 15.7 & 18.8 & $29.8 \%$ \\
\hline China & 24762 & 346694 & 1.3 & 5.5 & $130.0 \%$ \\
\hline Hong Kong, Chi & 162665 & 469776 & 8.6 & 7.4 & $18.9 \%$ \\
\hline India & 1667 & 18971 & 0.1 & 0.3 & $103.8 \%$ \\
\hline Indonesia & 38883 & 60638 & 2.1 & 1.0 & $5.6 \%$ \\
\hline Korea, Republiı & 5186 & 42329 & 0.3 & 0.7 & $71.6 \%$ \\
\hline Lao People's D $\epsilon$ & 13 & 659 & 0.0 & 0.0 & $515.1 \%$ \\
\hline Malaysia & 10318 & 54315 & 0.5 & 0.9 & $42.6 \%$ \\
\hline Pakistan & 1928 & 10611 & 0.1 & 0.2 & $45.0 \%$ \\
\hline Philippines & 3268 & 12688 & 0.2 & 0.2 & $28.8 \%$ \\
\hline Singapore & 28565 & 89250 & 1.5 & 1.4 & $21.2 \%$ \\
\hline Sri Lanka & 681 & 2465 & 0.0 & 0.0 & $26.2 \%$ \\
\hline Taiwan Provinc & 9735 & 27924 & 0.5 & 0.4 & $18.7 \%$ \\
\hline Thailand & 8209 & 24165 & 0.4 & 0.4 & $19.4 \%$ \\
\hline Viet Nam & 230 & 17956 & 0.0 & 0.3 & $771.1 \%$ \\
\hline Total above & 296107 & 1178440 & 15.7 & 18.7 & $29.8 \%$ \\
\hline $\mathrm{NICs}$ & 206150 & 629279 & 10.9 & 10.0 & $20.5 \%$ \\
\hline NICs+ China & 230912 & 975973 & 12.2 & 15.5 & $32.3 \%$ \\
\hline Late NICs & 60677 & 151806 & 3.2 & 2.4 & $15.0 \%$ \\
\hline Asia less above & 5692 & 56174 & 0.3 & 0.9 & $88.7 \%$ \\
\hline
\end{tabular}


Table 5: Motivation of FDI in Latin America

\begin{tabular}{|c|c|c|c|}
\hline Sector/objective & Primary & Manufacturing & Services \\
\hline $\begin{array}{l}\text { Natural resource- } \\
\text { seeking }\end{array}$ & $\begin{array}{l}\text { Petroleum and gas: } \\
\text { Venezuela, } \\
\text { Colombia, Argentina } \\
\text { Minerals: Chile, } \\
\text { Argentina, Peru }\end{array}$ & & \\
\hline $\begin{array}{l}\text { Market-seeking } \\
\text { (manufactures) }\end{array}$ & & $\begin{array}{l}\text { Automotive: } \\
\text { Mercosur } \\
\text { Chemicals: Brazil } \\
\text { Agro-industry: } \\
\text { Argentina, Brazil, } \\
\text { Mexico }\end{array}$ & \\
\hline $\begin{array}{l}\text { Market-seeking } \\
\text { (services) }\end{array}$ & & & $\begin{array}{l}\text { Financial services: } \\
\text { Brazil, Mexico, } \\
\text { Chile, Argentina } \\
\text { Telecommunications } \\
\text { brazil, Argentina, } \\
\text { Chile, Peru } \\
\text { Electrical energy: } \\
\text { Colombia, Brazil, } \\
\text { Argentina, Central } \\
\text { America }\end{array}$ \\
\hline Efficiency seeking & & $\begin{array}{l}\text { Automotive: Mexico, } \\
\text { Brazil } \\
\text { Electronics: Mexico, } \\
\text { carribean basin } \\
\text { Apparel: caribbean } \\
\text { basin, Mexico }\end{array}$ & \\
\hline $\begin{array}{l}\text { Strategic asset- } \\
\text { seeking }\end{array}$ & & & \\
\hline
\end{tabular}

Source: Mortimore (2000) 
Table 6: indicators of absorptive capacity

$\begin{array}{ll}\text { Telephone lines } & \text { tertiary enrolment, } \\ \text { per } 1000 \text { residents } & \text { share of population }\end{array}$

BERD (as a \% of GDP)

\begin{tabular}{lrr|rr|rr} 
& 1985 & 1998 & 1985 & 1998 & 1985 & 1998 \\
Asia & & & & & & \\
Singapore & 324 & 562 & 0.71 & 0.47 & 0.2 & 0.69 \\
HK & 323 & 557 & 0.49 & 0.49 & & 0.01 \\
Korea & 159 & 432 & 0.78 & 1.65 & 0.48 & 2.1 \\
Taiwan & 228 & 420 & 0.59 & 1.06 & 0.6 & 0.99 \\
Malaysia & 62 & 198 & 0.08 & 0.13 & 0.01 & 0.17 \\
Thailand & 12 & 84 & 0.16 & 0.19 & 0.02 & 0.01 \\
China & 3 & 96 & 0.08 & 0.1 & & 0.16 \\
India & 4 & 22 & 0.15 & 0.12 & 0.14 & 0.12 \\
& & & & & & \\
Latin America & & & & & & \\
Chile & 44 & 205 & 0.52 & 0.73 & & \\
argentina & 90 & 203 & 0.68 & 0.47 & & 0.13 \\
Colombia & 57 & 174 & 0.36 & 0.51 & & \\
Cost Rica & 80 & 172 & 0.31 & 0.34 & & 0.12 \\
Brazil & 53 & 120 & 0.16 & 0.18 & 0.07 & 0.32 \\
venezuela & 70 & 117 & 0.56 & 0.45 & 0 & 0.07 \\
Peru & 21 & 67 & 0.47 & 0.46 & & 0.01 \\
mexico & 49.5 & 103.6 & 0.48 & 0.44 & 0.14 & 0.05
\end{tabular}

Source: UNIDO Industrial Development Report 2002/2003 (Table A 2.13. A2.23, A2.19) 
Table 7: US Patent applications, selected developing countries, selected period

1985-89 1995-1999 1985-89 1995-1999

LAC

Argentina

Bolivia

sum

average annual

Brazil

Chile

Colombia

Costa Rica

$201 \quad 435$

40.2

0.8

87

Dominican Repub

El Salvador

Guatemala

Guyana

Haiti

Jamaica

Mexico

Nicaragua

Paraguay

Peru

4
390

390

45
10

745

83

10

67

38

10

11

4

12

11

0

4

$6 \quad 14$

$371 \quad 594$

594
2

5

Trinidad and Toba

Uruguay

Venezuela, RB

4

15

187

2251

78

1.6

$5 \quad 13.4$

27.6

$2 \quad 2.2$

$0.6 \quad 0.8$

$2.2 \quad 2.4$

0

$1.2 \quad 2.8$

$\begin{array}{ll}74.2 & 118.8\end{array}$

0.4

$\begin{array}{ll}0.4 & 1\end{array}$

$\begin{array}{ll}6.4 & 4.6\end{array}$

$\begin{array}{ll}2.8 & 0.8\end{array}$

3

$\begin{array}{rr}37.2 & 37.4 \\ \mathbf{2 6 4 . 4} & \mathbf{4 5 0 . 2}\end{array}$

South asia

Bangladesh

India

Pakistan

Sri Lanka

East Asia

Hong Kong, China

Indonesia

Korea, Rep.

Malaysia

Philippines

Singapore

Thailand

Taiwan

China

Total EA

Toatl developing

0

0

0

$\begin{array}{llll}178 & 794 & 35.6 & 158.8\end{array}$

8

16

1.6

158.8
3.2

815

37.6

163

Global total

65993

DC As \%

$1.5 \%$

$5.3 \%$

$1.5 \%$

$5.3 \%$

East asia As \%

$1.2 \%$

$5.1 \%$

$1.2 \%$

$5.1 \%$

LAC as \%

$0.2 \%$

$0.2 \%$

$0.2 \%$

$0.2 \%$

Source: US patent and Trademark office 2000 
Figure 1: FDI distribution by sector, 1988 and 1999

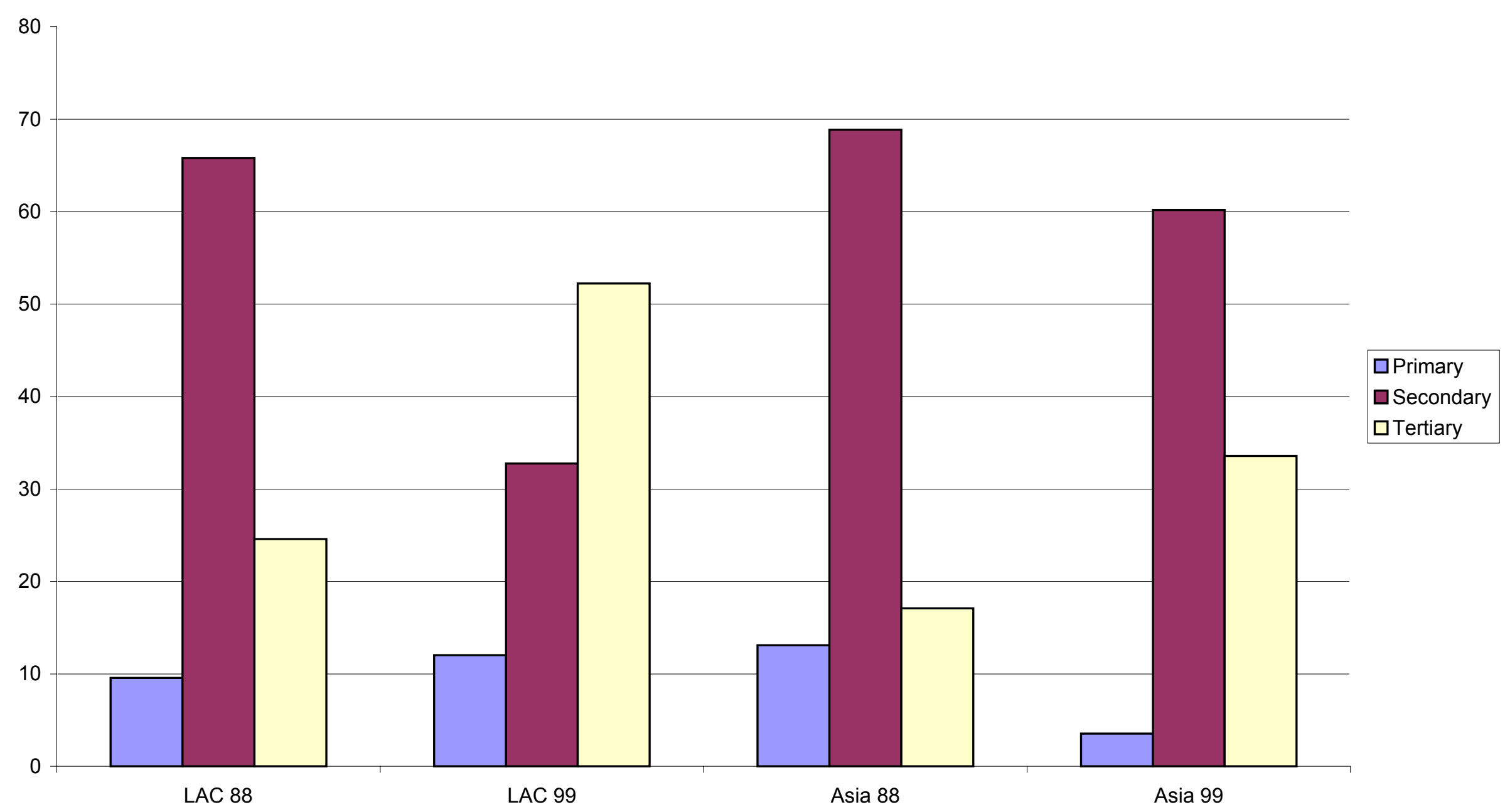


Figure 2: Latin America, share in global sectoral total

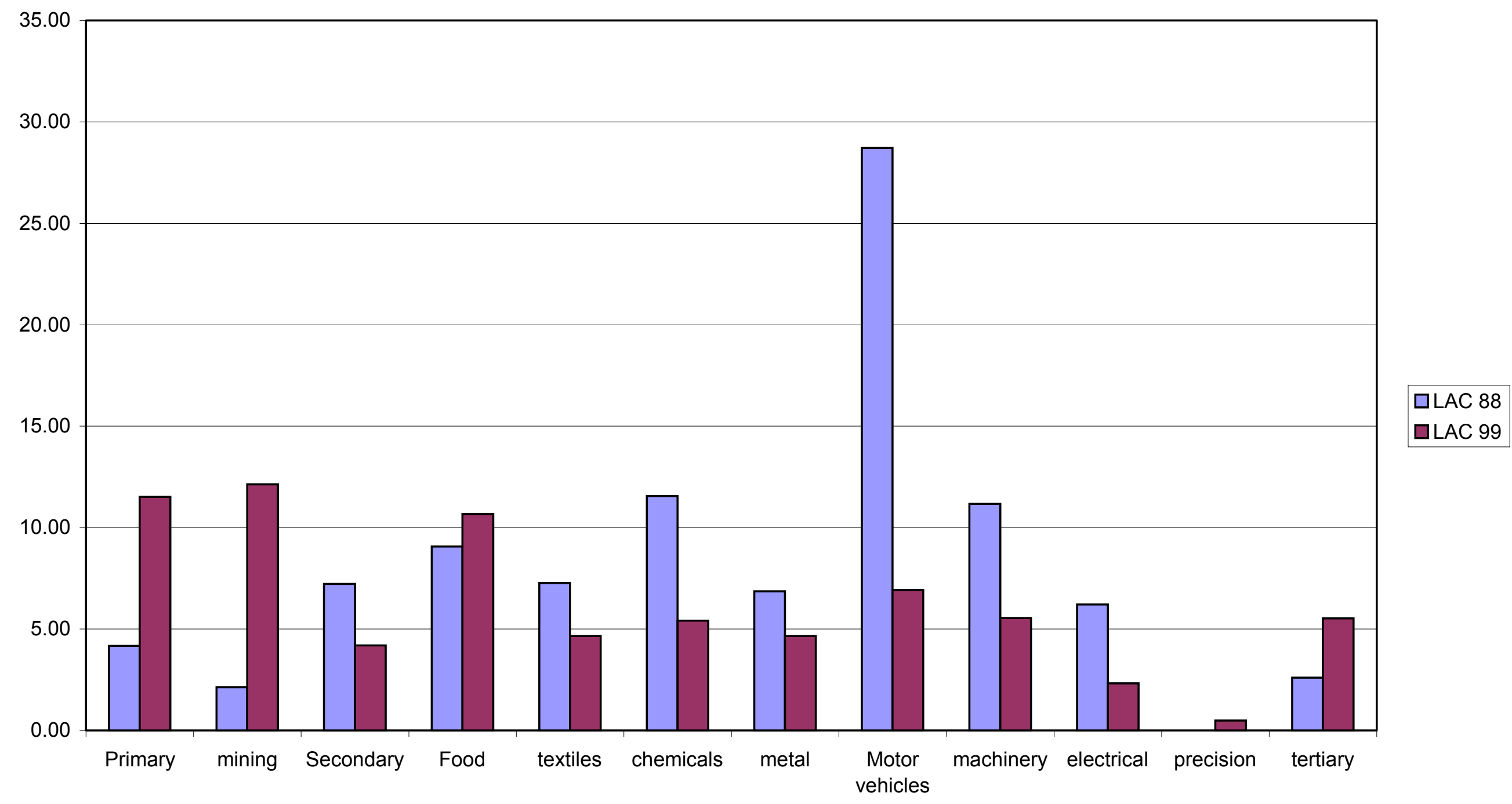


